\title{
Basin scale transport in stratified lakes and reservoirs: towards the knowledge of freshwater ecosystems
}

\author{
Francisco Rueda Valdivia
}

Instituto del Agua y Departamento de Ingeniería Civil - Universidad de Granada. C/Ramón y Cajal, 4 - 18071 Granada. Spain.fjrueda@ugr.es

\begin{abstract}
The physical processes of transport and mixing exerts a profound influence on the biogeochemistry of aquatic systems: not only they determine the position of particulate and dissolved substances contained in the water at any given time, but they also contribute to determine the environment in which biogeochemical reactions occur. The physical behaviour of four aquatic systems are examined, trying to illustrate the mechanisms of transport at play in any given environment as determined by both the properties of the external forcing and the characteristics of the system itself (morphology, in particular). Scaling arguments, based on Lake and Wedderburn numbers, the Rossby radius of deformation and the nominal residence time, provide a simple and first order four-dimensional framework in which one can sketch and classify the physical behaviour of the system. The four case examples analyzed occupy, in that four dimensional framework, positions which are far apart. Transport in natural systems is shown, by means of examples, to be a highly dynamic feature determined by the exact details of how mass and energy enters (their magnitude, frequency, exact location in time, their spatial variability). Some of those 'second order' effects, not captured in the first order analysis based on simple scales or non-dimensional parameters, are analyzed.
\end{abstract}

Keywords: transport, stratified lakes, basin-scale.

\section{RESUMEN}

Los procesos físicos de transporte y mezcla ejercen una influencia muy marcada sobre la biogeoquímica de sistemas acuáticos: no solo controlan la posición en el espacio y en un determinado momento de partículas en suspensión o sustancias disueltas en agua, sino que además contribuyen a fijar el ambiente en el que las reacciones biogeoquímicas tienen lugar En este documento se describen los mecanismos responsables del transporte en una serie de sistemas acuáticos naturales, como el resultado de la interacción entre fenómenos exógenos de forzamiento y las características de los propios sistemas (la morfología en particular). Argumentos de escala, basados en los números de Lago y Wedderburn, el radio de deformación de Rossby y el tiempo nominal de residencia, proporcionan un marco conceptual y de primer orden en el cual se puede definir y clasificar el comportamiento físico de los sistemas acuáticos. Los casos analizados corresponden a sistemas, que en este espacio de cuatro dimensiones, ocupan posiciones distantes entre sí. En este trabajo se muestra que la circulación y el transporte en sistemas acuáticos son fenómenos muy dinámicos, que en gran medida, están determinados por la magnitud, la frecuencia, la variabilidad espacial y su localización exacta en el tiempo de los flujos de masa y energía. Estos efectos, de 'segundo orden', son los que se analizan en este trabajo.

Palabras clave: transporte, lagos estratificados, escala cubeta.

\section{INTRODUCTION}

Ramon Margalef's Mandala (e.g. Margalef 1997) describes the composition of phytoplankton communities, the relative abundance of component species, and their evolution (succession) as the result of a nutrient-turbulence balance (see also Reynolds 1997). If we accept
Margalef's Mandala as a valid interpretation of succession in freshwater ecosystems, one necessarily concludes that the analysis and understanding of the functional structure of phytoplankton communities and its evolution needs to be grounded on the knowledge of the physical processes of transport and mixing determining turbulence levels and nutrient distribution in the 
water column. The physical processes of transport and mixing in lakes and reservoirs occur at a wide range of spatial and temporal scales, that go from the finest scales characteristic of turbulent motions $-O(\mathrm{~mm})$ and $O(\mathrm{~s})$ - to those characteristic of basin scale circulation $-O(\mathrm{~km})$ and $O(\mathrm{~d})$ - (e.g. Imboden and Wüest, 1995). Unfortunately and due to the small physical dimensions of the containing basin (compared to the ocean), transport processes in lakes and reservoirs are complex and, therefore, difficult to characterize and describe (Imberger 1998). Only in the last few years, the development of three-dimensional numerical models that solve the equations of motion with a high temporal and spatial resolution and low computational cost, together with the availability of technology capable of providing velocity and temperature field observations at a wide range of spatial and temporal scales, has allowed aquatic scientists to initiate the exploration of transport processes in natural lakes and reservoirs. My research has been devoted to the analysis of basin-scale transport patterns in stratified lakes and reservoirs and to the exploration of their consequences on the distribution of substances in these environments, using three-dimensional hydrodynamic models, scaling analysis and field observations. My approach to the knowledge of freshwater aquatic ecosystems (lakes and reservoirs in particular) is, therefore and fundamentally, a physical one. However, it should be understood within the framework of Ramon Margalef's vision of the structure and evolution of phytoplankton communities (Mandala), which suggests that physics has a role in determining the biology in aquatic ecosystems. My latest lines of research, recently initiated at the Water Institute in the University of Granada, in collaboration with several research groups in Aquatic Ecology from Southern Spain, attempt to examine the interactions between the structure of phytoplankton communities (functional and in terms of size) and the physical environment in reservoirs. This manuscript is a summary of some of the most relevant aspects of my previous work, which focuses on transport patterns in stratified lakes and reservoirs.

\section{TRANSPORT PROCESSES IN AQUATIC SYSTEMS: A BRIEF OVERVIEW}

Transport and mixing processes in aquatic systems, with the exception of molecular diffusion, are driven by fluxes of mass and energy (thermal and mechanical) that occur either through the free surface or through inflow or outflow sections (Fischer et al., 1979; Imboden and Wuest 1995). These fluxes are subject to spatial and temporal variations at a wide range of scales. For example, the heat fluxes through the free surface of a lake change at temporal scales ranging from sub-daily (characteristic of diel cycles of heating and cooling) to interannual scales (a feature of climate cycles). Mechanical energy fluxes on the other hand, either through the free surface (as a consequence of wind) or through the inflow or outflow sections occurs in pulses or events: wind is not continuously blowing over the surface of a lake, but it occurs as events with varying frequency, intensity and duration; inflow in reservoirs is maximal during rainfall events; outflows in reservoirs are subject to changes dictated by water demands, which in the case of hydroelectric power, for example, has peaks followed by periods of low demands. The specific transport patterns, either at the basin-scale or at the finest scale of turbulence, that develop in response to mass or energy fluxes depend on a balance of mass and energy fluxes and the specific spatial and temporal patterns characterizing the fluxes (the frequency, intensity, duration and location in time of the events), together with characteristics of the aquatic systems, as their morphometry (Imboden and Wuest 1995). It is a balance of energy fluxes what determines, for example, the stratification in aquatic systems and its evolution in time: stratification develops if and when the magnitude of fluxes inducing density gradients in the water column (e.g. heating through the free surface) is larger than the fluxes that introduce kinetic energy available to mix it (i.e. wind or cooling at the free surface).

Atmospheric (wind) or hydrologic events acting on a stratified water body tend to perturb its equilibrium status by tilting the isotherms. 

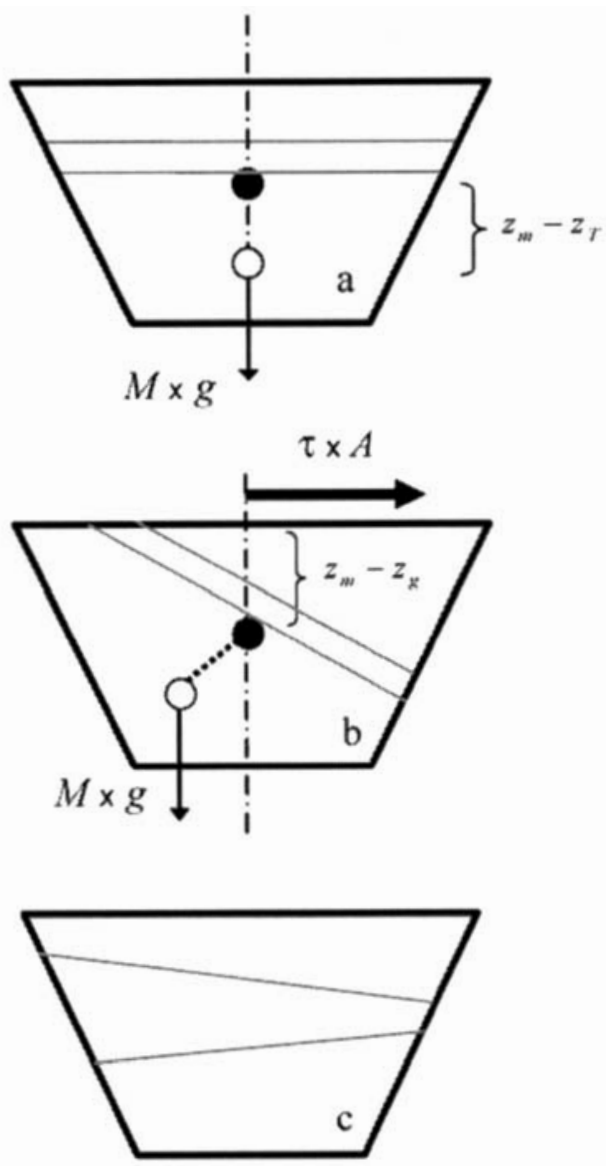

Figure 1. Response of a stratified lake to wind forcing: (a) A system in equilibrium, with horizontal isotherms (thin lines). The centre of volume is represented with a solid dark circle, while the empty circle shows the location of centre of mass (displaced towards the bottom from the centre of volume, due to stratification). (b) The destabilizing moments are associated to wind force applied to the free surface, separated $z_{m}-z_{\mathrm{g}}$ from the centre of volume. The stabilizing moments are associated to gravity forces acting on the centre of mass. Diagram b shows a mode 1 response to wind: the metalimnion moves towards the surface at the upwind end of the lake. (c) Mode 2 response: isotherms open at the upwind end, and compress at the downwind end. Respuesta de un sistema estratificado frente al viento. (a) Sistema en equilibrio con isotermas en posición horizontal. La posición del centro del volumen aparece marcada con un punto negro, y la del centro de masas con un círculo con el interior en blanco. El centro de masas, como consecuencia de la estratificación queda por debajo del centro de volumen. (b) El viento, aplicado a la superficie del lago, ejerce una acción desestabilizadora sobre el sistema. La acción estabilizadora le corresponde a la fuerza de la gravedad que actúa sobre el centro de masas. El diagrama b muestra un respuesta de modo 1 frente al viento: el metalimnion se mueve hacia la superficie en la zona de barlovento (c) Respuesta de modo 2 frente a fenómenos perturbadores: las isotermas se abren en la zona de barlovento, y se comprimen en la zona de sotavento.
The behaviour of stratified systems of small and medium-size in response to those perturbation events can be parameterized using the adimensional Lake $L_{N}$ and Wedderburn $W$ numbers. These numbers relate the magnitude of the external forces acting upon the system and displacing it from its equilibrium status to the forces that tend to re-establish the original equilibrium status as the system is displaced from it (gravity). The Lake number $L_{N}$ is defined as the ratio between the stabilizing and the destabilizing moments referred to the centre of volume (Fig. 1). In the particular case of wind forcing acting upon a stratified system $L_{N}$ can be estimated as (e.g. Imberger and Patterson 1990)

$$
L_{N}=\frac{\left(z_{g}-z_{0}\right) \operatorname{Mg}\left(z_{m}-z_{T}\right)}{\rho u_{*}^{2} \mathrm{~A}^{3 / 2}\left(z_{m}-z_{g}\right)}
$$

Here, $z_{g}$ is the elevation of the center of volume, $z_{0}$ is the elevation of the center of mass, $z_{m}$ is the elevation of the free surface and $z_{T}$ is the elevation of the thermocline or the center of the metalimnion. The magnitude of the destabilizing force is related to $u_{*}$, the friction velocity of the wind force is, in this case, applied tangentially to the free surface and is given by the product of $\tau$, the shear stress $\tau$ (presumed uniform over the lake surface), by the surface area $A$. The shear stress, in turn, can be estimated as,

$$
\tau=C_{D} \rho_{a} U_{a}^{2}=\rho u_{*}^{2}
$$

where $C_{D}$ is the drag coefficient for wind $\left(\approx 1.5 \times 10^{-3}\right), \rho_{a}$ is the air density, $U_{a}$ is the wind speed, $\rho$ is the water density. The Wedderburn number $W$ is estimated as (Imberger and Patterson 1990),

$$
W=\frac{1}{L} \frac{g^{\prime} h^{2}}{u_{*}^{2}}
$$

where $g^{\prime}$ is the reduced gravity $(=g \Delta \rho / \rho), h$ is the thickness of the surface mixed-layer and $L$ is the length of the basin. For $L_{N}>>1$, the restoring force is larger than the forces perturbing the system, and the tilting of the isotherms is small 
compared to the thickness of the epilimnion (Stevens and Imberger 1996). For $L_{N}<<1$, the external forcing will generate significant horizontal gradients in the thermal and chemical characteristics of the lake. In the case of wind, deep hypolimnetic water will reach the surface in the upwind end. On the other hand, low values of the Wedderburn number $(W \sim O(1)$ o $W<1)$ correspond to scenarios in which isotherms open in the upwind end, while they compress in the downwind end of the lake. This type of response is known as mode 2 , while the behaviour defined by the condition $L_{N}<<1$ is known as vertical mode 1 (Fig. 1). For the particular case of systems with a thin metalimnion, $W$ and $L_{N}$ coincide.

Lake and Wedderburn numbers not only parameterize the large-scale behaviour of aquatic systems. As shown by Fischer et al., 1979 (among others), the values taken by $L_{N}$ and $W$ are also indicative of the nature of the dominant processes leading to mixing in the water column. For $W>1$, mixing is driven by the direct flux of turbulent kinetic energy through the free surface (caused by processes like wave breaking, etc), which in the literature is known as stirring (Fischer et al., 1979). For $W \sim O(1)$ o $W<1$, on the other hand, mixing is energized by turbulent fluctuations driven by shear (velocity gradient) in the water column. Shear driven turbulence and mixing, acting upon horizontal gradients - induced by basin-scale motions for $W \sim O(1)$ or $W<1-$ drive, in turn, longitudinal dispersion processes that tend to mix the hypolimnetic o metalimnetic water upwelled in the upwind end of the lake with the surface water accumulated in the downwind end. Hence, $W \sim O$ (1) o $W<1$ is indicative of vigorous mixing processes (horizontal and vertical) leading to smeared physico-chemical gradients and thick metalimnetic layers.

In relatively shallow and enclosed water bodies, the condition $W \sim O$ (1) o $W<1$ occurs on a frequent basis, and consequently, these systems tend to exhibit a weak (almost linear) and intermittent stratification. These are lakes that mix vertically several times during a year, i.e. polymictic lakes. In these systems, wind -its time and spatial distribution-determines, to a large extent, the transport patterns. The work of Rueda et al. (2003a), Rueda and Schladow (2003b) and Rueda et al. (2005a), suggests that thermal stratification, though weak and intermittent, may also play a major role in determining water motions in polymictic systems during the stratified periods (see section 3). In deeper lakes and reservoirs, stratification is more stable $(W>>1)$ and the system undergoes through a unique period during a year in which the water column mixes (monomictic lakes) due to surface cooling. Water motion, in these systems, is almost totally dominated by internal waves, motions of all scales and frequencies which cause isopycnals to oscillate with some well-defined frequency (Imberger 1998). Internal waves at the basin scale are directly excited by the wind forcing acting directly on the free surface. Once established, basin-scale internal waves steepen due to non-linear processes and to shoaling, forming a spectrum of internal wave motions with frequencies ranging from $10^{-6}$ to $10^{-2} \mathrm{~Hz}$. The energy of the internal wave field is finally dissipated within the benthic boundary layer (Imberger 1998) through wave breaking or shear driven processes. Section 4 presents some results of work done on the analysis of basin-scale internal waves in Lake Tahoe, its temporal and spatial structure. This work suggests that, also in deep lakes, the frequency, duration and intensity of wind events are factors that need to be taken into account to understand the internal wave climate, and hence mixing processes. My interest on basinscale internal waves is justified in that they provide the main driving force for vertical and horizontal transport in deep stratified lakes (Imberger 1998, MacIntyre et al., 1998). Hence, the first step towards analyzing numerically the dynamics of nutrients and particles in deep lakes consists on being able to understand and represent with three-dimensional transport models the energy and spatial characteristics of basin scale internal waves.

Upwelling events, either episodic or more frequent, its intensity and duration control the exchange of water between basins connected 


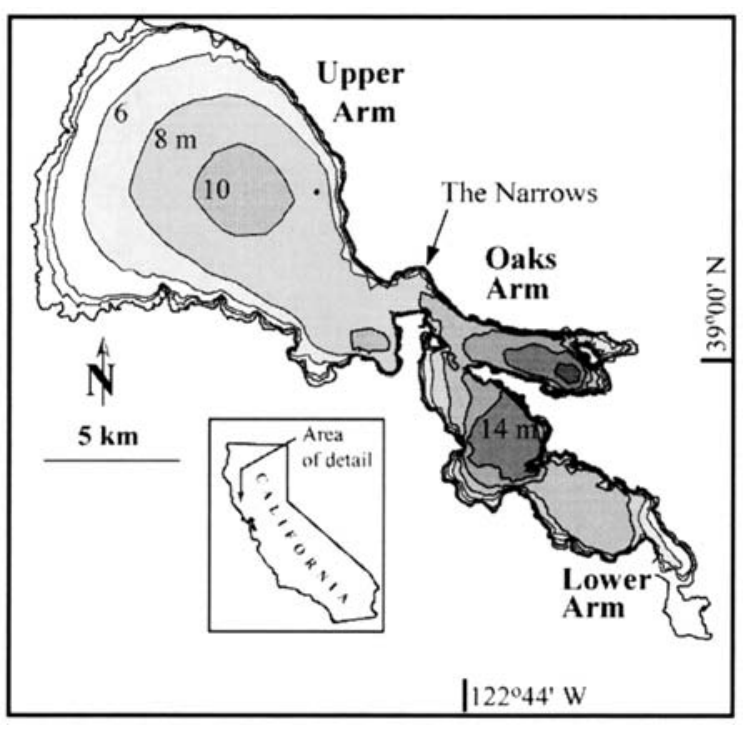

Figure 2. Bathymetry map (in gray) of Clear Lake with contours shown every $2 \mathrm{~m}$. Inset on left locates Clear Lake in California, USA. Also shown are the three basins of the lake, connected at the Narrows. Batimetría del Lago Clear, con contornos cada $2 \mathrm{~m}$. En el recuadro de la izquierda se muestra la localización del lago en California, EEUU. Así mismo, se muestran los nombres y disposición de las tres subcuencas del lago, conectadas en el estrecho de 'Narrows'.

through narrow straights. Section 4 shows the results of some work done on exchage processes in semi-enclosed environments, applied to a particular embayment of Lake Ontario. Reservoirs, are considered open systems, where mass and energy is exchanged through distinct inflow and outflow sections. Inflow mixing controls the pathways of river nutrients in the reservoir and, in particular, the extent to which these nutrients can reach the euphotic zone to be used as resources for primary production. Moreover, the transport processes that occur at the river inflow sections, interacting with selective withdrawal (outflow) and vertical mixing processes driven by wind or surface cooling, control the average time a given water parcel remains within the reservoir. This time scale, known was the hydraulic residence time, has been proposed in the literature to explain a wide range of water quality processes. Section 5 , presents results of work undertaken to estimate the residence times in reservoirs, as systems with large fluctuations in water level and inflow-outflow rates.

\section{CIRCULATION PATTERNS IN POLYMICTIC LAKES}

Mixing and transport in large polymictic lakes has received little attention in the limnological and engineering literature. Instead most physical limnology has focused on the dynamics of deep, seasonally stratified lakes which are characterized by the presence of a vertical thermal stratification that evolves on a time scale of months, and free basin-scale internal waves with time scales on the order of hours to days (e.g. Antenucci et al., 2000; Hodges et al., 2000; Pan et al., 2002; among many others). One of the few attempts to describe transport patterns in a shallow polymictic lake is the series of three papers - Rueda et al. (2003a), Rueda and Schladow (2003) and Rueda et al. (2005a) - recently published in the peer reviewed literature. The results described in those publications are the result of a study conducted in Clear Lake (Fig. 2), during several periods in 1995, 1997 and 1999. Clear Lake is a large polymictic lake in northern California with three sub-basins (Oaks, Upper and Lower arms) separated by a narrow straight (Narrows). With an average annual inflow $Q$ estimated to be $514 \times 10^{6} \mathrm{~m}^{3} /$ year (Lynch 1996 ) the ratio $V / Q$ (where $V$ is the average lake volume) is approximately two to three years. Hence, advective flow (through-flow) through the lake is not considered to be a major factor in determining largescale circulation. As with many other large and polymictic systems, Clear Lake does not support free basin-scale internal waves since the wave periods are, in general, longer than the time scales associated with the stratification-destratification cycles. Maximum recorded temperature differences between the top to the bottom of the lake (max. depth is c.a. $15 \mathrm{~m}$ ) were of up to $6^{\circ} \mathrm{C}$ in 1999 (Rueda et al., 2003). On a typical summer day the winds are primarily from the northwest, minimal between midnight and dawn and reaching a maximum about dusk. Also, and due to the large extent of Clear Lake and the irregular nature of its surrounding topography, the wind exhibits a considerable degree of spatial variability. These two characteristics 
of the wind field (its marked diurnal periodicity and its spatial variability) are key features, together with the weak stratification, to explain circulation patterns in the lake.

\section{Wind-stratification interaction in weakly stratified systems}

This research focused on one of the sub-basins of Clear Lake: the Oaks arm. The evening winds (blowing along the thalweg of the sub-basin) encounter a water column, which due to the surface heat flux during the morning and early afternoon hours, is stratified. The wind acts on this weakly stratified system to generate strong horizontal temperature gradients along the axis of the Oaks Arm $(W<<1)$, which can be of up to $3^{\circ} \mathrm{C}$ in hardly $4 \mathrm{~km}$. Deep water rises at the western end of the arm, near the Narrows. Due to the weak stratification, rotational effects modulate the response of the lake to wind forcing, causing upwelling of deep water also on the north shore of the Oaks Arm. The effect of the Earth's rotation on a stratified system being forced by wind can be analyzed using the theoretical model proposed by Csanady (1982). In that model, it is assumed that a long-shore wind is applied impulsively on an initially quiescent and semi-infinite (i.e. only bounded on one side) two-layer system of depth $H$. The interface will tilt perpendicular to the wind direction and it will intersect the water surface - complete upwelling - if the wind impulse $I\left(=u_{*}^{2} t, \mathrm{t}\right.$ being time) satisfies the condition

$$
I(H-h) / h H c_{1} \geqslant 1
$$

where $h$ is the thickness of the upper layer and $c_{1}$ is the speed of propagation of perturbations in the interface (i.e. internal wave speed). For the Oaks arm, presuming a two-layer stratification with the interface at mid-depth and a density change equal to half the density difference from top to bottom, the ratio in Eq. 4 was on average, for the wind events occurring on a 15day period in may 1999 , equal to 1.64 . Hence, deep cold water piles up in the northwestern shores in response to northwesterly winds (see

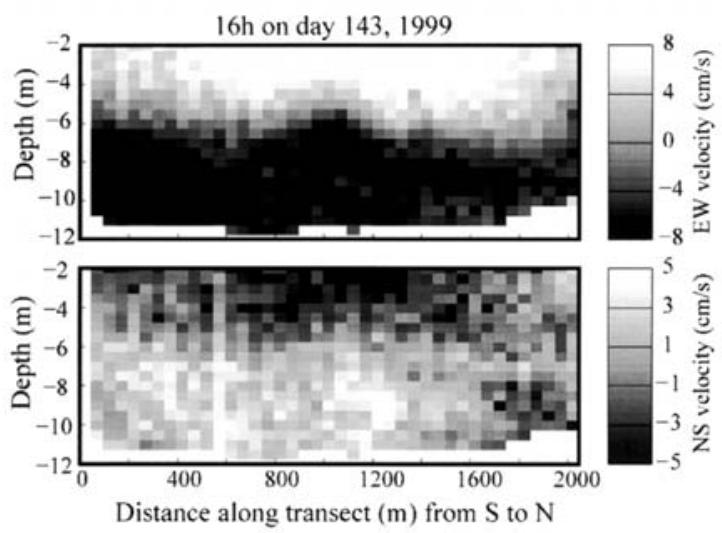

Figure 3. Transect taken on day 143, 1999 at $16 \mathrm{~h}$ across the Oaks Arm. Boat was moving from south to north. Velocity is given in $\mathrm{cm} / \mathrm{s}$ in gray scale of each plot. The component of velocity along the main axis of Oaks Arm is shown on top, and that in perpendicular direction on bottom of the figure, and gray scale to left of value of velocity component (positive is eastward). Transecto de velocidad realizado a las $16 \mathrm{~h} \mathrm{del} \mathrm{dia}$ 143, 1999 de sur a norte en Oaks Arm. La velocidad se muestra en $\mathrm{cm} / \mathrm{s}$ utilizando una escala de grises (a la derecha). Arriba se muestra el componente de velocidad u paralelo al eje principal de Oaks arm. Abajo se muestra el componente de velocidad $v$ perpendicular a dicho eje. Valores positivos son hacia el este y hacia el norte para $u$ y $v$ respectivamente.

circulation patterns in figure 3 captured with an acoustic Doppler Profiler ADCP). During the night and early morning hours, when the wind forcing is negligible, the pressure gradients that result from the horizontal differences in temperature become the dominant forcing mechanism in the system, driving currents of up to $10-15 \mathrm{cms}^{-1}$, westward at the surface and eastward near the bottom (Fig. 4), that try to bring isotherms to their equilibrium horizontal position. The currents during the relaxation of the horizontal temperature gradients are affected by the Earth's rotation, and westward currents mainly occur through the north shore.

\section{Residual circulation patterns}

The cycle of setup and relaxation of horizontal temperature gradients driven by wind and modulated by the Earth's rotation, shown in the previous section, repeats in the stratified lake with a diurnal periodicity. As a result, a residual cyclonic circulation develops, which facilitates horizontal exchange processes in the lake. A particle 


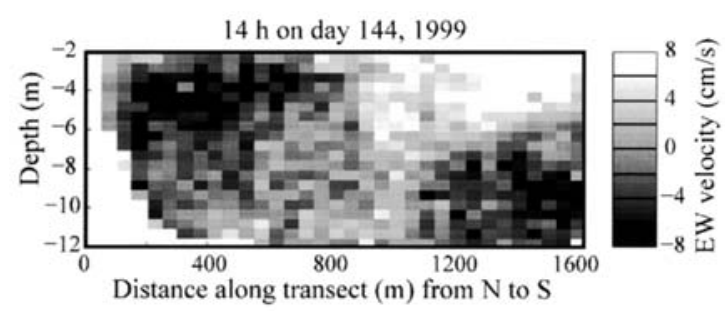

Figure 4. Transects taken at $14 \mathrm{~h}$ on day 144,1999 . The gray scale represents the magnitude $(\mathrm{cm} / \mathrm{s})$ of velocity component along main axis of Oaks Arm (positive is eastward). Transecto de velocidad realizado a las 14 h del día 144, 1999 de sur a norte en Oaks Arm. La escala de grises muestra el componente de velocidad u paralelo al eje de la subcuenca $(\mathrm{cm} / \mathrm{s})$. Valores positivos son hacia el este.

left in the Oaks Arm would describe counterclockwise trajectories. This circulation pattern was revealed experimentally, using lagrangian followers, and numerically, using simulations of tracer release experiments and particle tracking techniques. Details of the modelling tools employed (here and throughout this work) can be found in Rueda and Schladow 2003 or Smith 1997. Figure 5, for example, shows the sequence of positions of a particle released near the easternmost end of the Oaks Arm. To describe the particles' 3-D trajectories, plan-view (2-D) plots have been used, in which the depth below the surface of the particle is indicated by the grayscale of the marker used to show its horizontal position. Each dot represents the position of a particle, in which is shown every hour. An increased spacing between positions indicates higher velocities. Figure 5 shows the trajectory of a particle that, after plunging and rising twice at the downwind end of the Oaks Arm, is carried in day 142 (1999) by surface currents to the westernmost end of the Oaks Arm, and from there it enters the Lower Arm. The particle plunges following the winddriven downwelling currents close to the mine, and it rises to the surface at the embayment located at the southwest edge of the Oaks Arm.

\section{Direct wind-driven circulation patterns}

In the Lower Arm the particle shown in figure 5 describes several clockwise loops. As shown in Rueda et al. (2005a), the anticyclonic circulation revealed by the particle trajectories (and also by observations gathered in 1995 with ADCP) is driven by the spatial variability of the wind field. In Clear Lake, sheltering by surrounding terrain is the major source of variability in the wind field. The topography of the landscape surrounding Clear Lake is complex and dominated by the presence of Mount Konocti, a dormant volcano rising over $900 \mathrm{~m}$ above the lake level. It is located upwind of the Lower arm in the direction of the predominant winds. The spatial variability of the wind field over Clear Lake was analyzed during two weeks starting on May 18, 1999, using an array of 14 anemometers. Vorticity is defined as twice the angular velocity of a fluid parcel and is used as a measure of the spatial variability of a flow field and its rotational character. As shown in figure 6, Mount Konocti modifies the wind field over the lake and creates areas of negative vorticity (anticyclonic or clockwise wind circulation) over the Lower Arm. The numerical simulations of Rueda et al. (2005a) show that the anticyclonic circulation patterns observed in the Lower Arm are not but the fingerprints of the anticyclonic wind circulation existing above it. Furthermore, it was shown that the spatial variability of winds increases the rate at which the Oaks Arm exchanges water mass with the rest of the lake, mainly with the Upper Arm, while it isolates the Lower Arm from the other two arms by increasing the recirculation rate (gyre formation) within this basin. The exchange rates between the Oaks and the Upper arms, for example, were almost twice the exchange rates between the Oaks and the Lower Arms under the spatially variable winds. Data collected in the last few years (Suchanek, pers.comm.) has shown that the annual loading to the sediment of particulate mercury is highest in the Oaks Arm, followed by the Upper Arm and then the Lower Arm (in the ratio of approximately 9:5:2). The ratio of loadings in the Upper and the Lower arms is approximately the same as the ratio of mass exchange rates of those two arms with the Oaks Arm, revealed by tracer simulations conducted in Rueda et al., 2005a. The coincidence of loading and exchange rate ratios among the different basins suggests a close link between chemical and hydrodynamic behaviour, which is driven by spatially variable winds. 


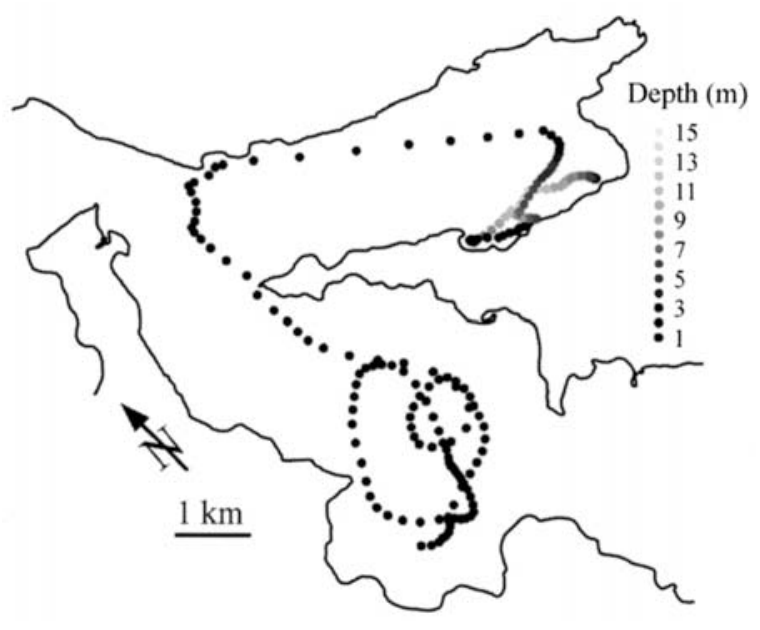

Figure 5. Trajectories followed by one of the groups of particles released near the eastern of the Oaks arm (Clear Lake) in the particle tracking simulations. Symbols are plotted one hour apart. The gray scale on the left shows the depth of the particle in the three-dimensional domain. Trayectoria seguida por una de las partículas liberadas en ejercicios numéricos de seguimiento de particulas en el extreme oriental de Oaks Arm (Lago Clear). Los símbolos representan la posición de la partícula en pasos de tiempo de una hora. La escala de grises representa la profundidad.

\section{BASIN SCALE INTERNAL WAVES IN DEEP STRATIFIED LAKES}

Lake Tahoe (Fig. 7) is located along the crest of the Sierra Nevada mountain range, between California and Nevada at an altitude of $1898 \mathrm{~m}$. It has a maximum depth of $505 \mathrm{~m}$, an average depth of $313 \mathrm{~m}$, and its surface area is $501 \mathrm{~km}^{2}$. The lake contains $156 \mathrm{~km}^{3}$ of water, and the ratio of the lake volume to the average outflow rate $V / Q$ is approximately 650 years. Typically, thermal stratification commences around March and reaches a maximum in August, at which time the top of the thermocline is approximately $20 \mathrm{~m}$ below the water surface. Slow weakening of the stratification may lead to approximately isothermal conditions by February in about one year in four (Jassby et al., 1999). As revealed by field data collected in Lake Tahoe since 1995 (see Thompson 2000), the temperature structure of the lake is subject to oscillations (internal waves) of varying amplitude, occurring at a range of frequencies. The work of Rueda et al., (2003b) analyzes temperature observations collected during a 25-day period at the end of
1999 , to determine the nature of those internal waves, its frequency and spatial characteristics, and the factors controlling the energy contained in the internal wave field. Thermistors were deployed at different depths and at two stations in Lake Tahoe (MIDLAKE and INDEX stations in figure 7). The average temperature profile during the 25-day period studied in Rueda et al. (2003b), is characterized by a relatively smooth gradation in temperatures from the epilimnion, with an almost uniform temperature of $7.5^{\circ} \mathrm{C}$ in the first 50 meters of the water column, to the hypolimnion starting at about $150 \mathrm{~m}$ below the water surface and having a uniform temperature of less than $5{ }^{\circ} \mathrm{C}$. The Lake $\left(L_{N}\right)$ and Wedderburn $(W)$ numbers are well above unity throughout this period, suggesting relatively small isotherm displacements compared to the thickness of the surface layer (no upwelling). Rather than analyzing thermistor records one by one, the temperature time series collected at different elevations $z$ was used to generate, for each station, a unique time series of integrated potential energy IPE, defined as

$$
\operatorname{IPE}(t)=\int_{z_{0}}^{z_{1}} \rho(z, t) g z \mathrm{~d} z
$$

It was the time series of IPE ( $t$ ) that was subject to spectral analysis to identify the frequencies of the most energetic oscillations. As shown by Antenucci et al., 2000, the IPE not only gives a clear and concise picture of the frequency content of the internal wave field, but it also represents correctly the relative distribution of potential energy among frequencies.

\section{Basin scale waves: a brief overview}

Basin scale internal waves are classified according to the horizontal and vertical structure of the isotherm displacements they induce. An internal wave of vertical mode 1 and horizontal mode 1 (V1H1) has only one node in the vertical and in the horizontal, as shown in figure 8a. Vertical mode 2 indicates the presence of more than one node in the vertical, i.e. two interfaces that oscillate with opposite phases compressing and expanding the metalimnion alternatively (see 


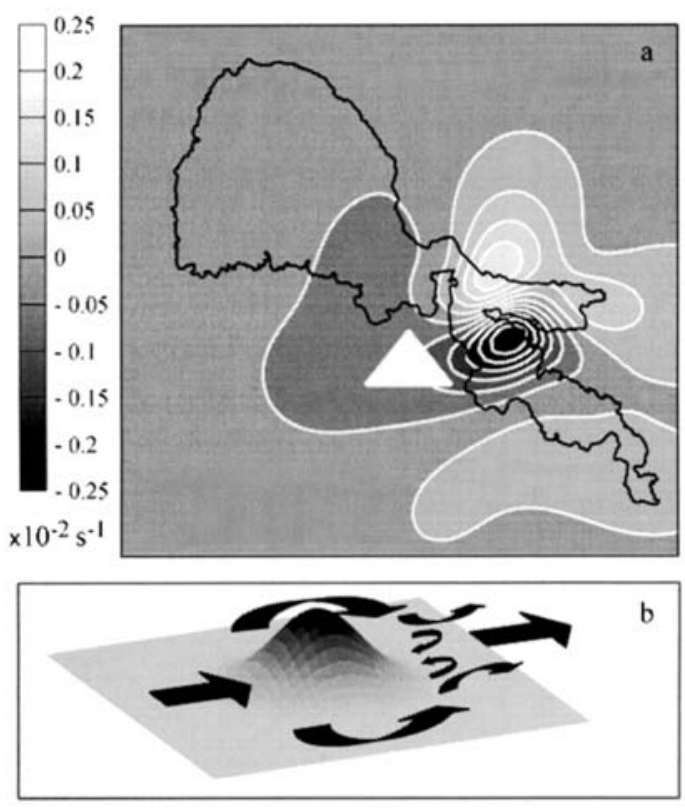

Figure 6. (a) Windfield vorticity constructed from wind records at $1700 \mathrm{~h}$ on day 139,1999 . The triangle represents the location of Mount Konocti. The effect of an isolated 3-D obstacle in a boundary layer flow is illustrated in panel $b$. The flow field past 3-D obstacles is characterized by the presence of a lee-side separation region and an associated wake. The wake contains two distinct counter-rotating horseshoe vortices (see panel a). The near-surface streamlines tend to diverge on the upstream side and converge on the downstream side of the obstacle (Baines, 1995). (a) Vorticidad del campo de viento construida a partir de registros de vientos en 14 estaciones meteorológicas situadas alrededor del Lago Clear a las $17 \mathrm{~h}$ del día 139, 1999. El triángulo blanco representa la localización del Monte Konocti (ver texto). El efecto de un obstáculo aislado en la capa límite atmosférica se ilustra en el panel (b). El campo de velocidades del fluido al pasar sobre el obstáculo está caracterizado por la presencia, en la zona de sotavento, de una región en que el fluido recircula. En la zona de recirculación existen dos vórtices con signos de rotación contrarios. Las lineas de flujo tienden a divergir en la zona de barlovento y a converger en la zona de sotavento (Baines, 1995).

figure $8 \mathrm{~b}$, showing a $\mathrm{V} 2 \mathrm{H} 1$ mode internal wave). Internal waves with horizontal modes two (and above) refer to the presence of two or more nodes in the horizontal direction (Fig. 8c). The spatial characteristics and oscillation periods of individual internal wave modes are controlled by the density stratification, the geometric properties of the enclosing basin, and, in the case of large lakes, by the Earth's rotation (e.g. Imboden 1990). The Earth's rotation can exert a significant influence on the internal

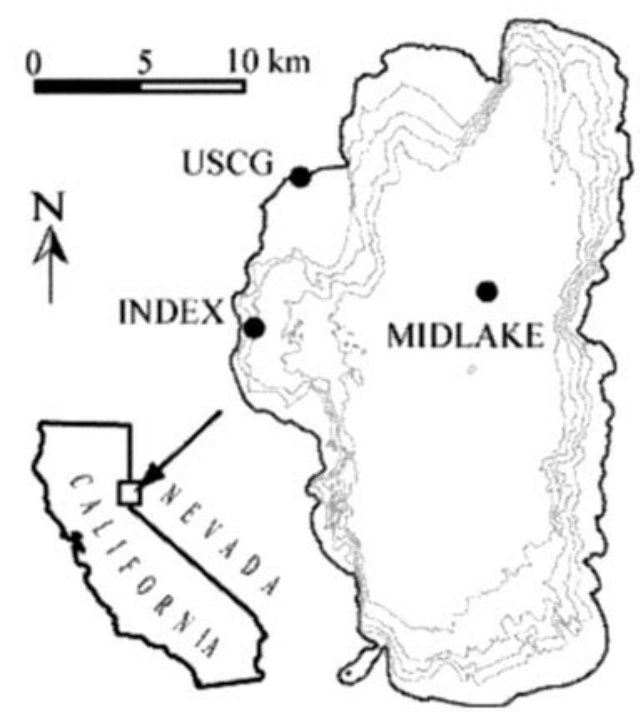

Figure 7. Lake Tahoe bathymetry (contoured on $100 \mathrm{~m}$ intervals) and instrument locations $(\bullet)$. Thermistor chain locations are MIDLAKE and INDEX. USCG indicates the location of the meteorological station. Batrimetría del Lago Tahoe, con contornos cada $100 \mathrm{~m}$. Se muestra también la localización de las ristras de termistores (estaciones MIDLAKE e INDEX) y de la estación meteorológica del Servicio Geológico de EEUU (USGS).

motions of lakes on temporal scales of the order of the inertial period ( 19 hours in Clear Lake) and on spatial scales of the same order as the Rossby radius of deformation $\left(\Lambda=c_{1} / f\right.$ where $f$ is the Coriolis parameter or inertial frequency). In Lake Tahoe during the period analyzed in Rueda et al., (2003b) $\Lambda$ is c.a. $3 \mathrm{~km}$ and smaller than the with of the basin $(19 \mathrm{~km})$, hence rotational effects are significant. Internal oscillations, under those conditions, are either Kelvin or Poincaré waves. Kelvin waves are long gravity waves with subinertial frequencies (periods larger than c.a. $17 \mathrm{~h}$ the inertial period) that are trapped at the boundaries of the lake. The perturbations travel cyclonically (counterclockwise) around a basin in the Northern Hemisphere with amplitudes exhibiting an exponential decay offshore with a scale of $O(\Lambda)$. The velocity fields show maxima at the boundaries (where the motion is rectilinear), and the current vectors in the lake interior rotate cyclonically (see for example Hutter 1984 or Antenucci and Imberger 2001). Poincaré modes are also progressive waves. In the Poincaré modes (or rotating internal seiches) the perturbations propagate 
anti-cyclonically with superinertial frequencies (periods lower than 17h). As shown by Antenucci et al. (2000), the isotherm displacements induced by a Poincaré wave measured in cross section have a standing structure and are, in general, undistinguishable from those induced by a linear seiche. Poincaré waves, however, differ from the linear seiches in that the velocity vectors rotate anti-cyclonically. The maximum amplitudes of the water velocity induced by the wave are observed at the center of the basin. Thus the origin of isopycnal oscillations (either a linear seiche or a Poincaré wave) can only be positively confirmed by inspection of the velocity vectors at a single location or inspection of temperature records from multiple locations.

\section{The internal wave 'zoo' in Lake Tahoe}

Figure 9 shows the power spectrum of $I P E$ signal, calculated from the temperature records collected at the INDEX station, exhibiting four peaks: three peaks in the subinertial range of the frequency, and one peak in the superinertial range. The three subinertial modes were identified as vertical mode one Kelvin waves travelling cyclonically around the perimeter of the lake with periodicities of approximately 128, 57 and $37 \mathrm{~h}$. The longer period Kelvin wave has horizontal mode 1, while the others have horizontal modes $2(57 \mathrm{~h})$ and $3(37 \mathrm{~h})$. The fourth internal wave mode was identified as a V1H1 one Poincaré wave having a period of about 17 $\mathrm{h}$, causing transverse oscillations of the isotherms. These results suggest that the internal oscillations in large lakes may be the result of the superposition of what Imboden and Wüest (1995) call a 'zoo' of basin-scale internal modes, rather than individual modes.

Figure 10 shows the spatial structure of IPE, as simulated by the $3 \mathrm{D}$ model, and its evolution in sequences of plots at quarter-period $(\mathrm{T} / 4)$ increments, for the three Kelvin wave modes identified in figure 9. Kelvin waves are seen travelling cyclonically around Lake Tahoe, with the shore on the right, and with one (Fig. $10 \mathrm{a}$, b, c, d), two (Fig. 10 e, f, g, h) and three (Fig. 10 $\mathrm{i}, \mathrm{j}, \mathrm{k}, \mathrm{l}$ ) peaks (zones with positive IPE values)
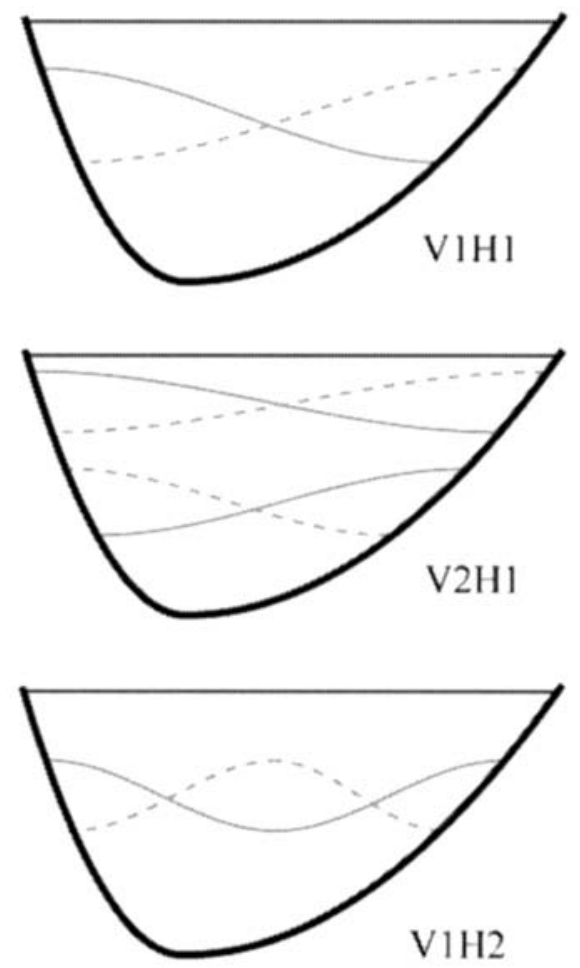

Figure 8. Idealized structure of internal waves. Here, it is assumed that isotherms (shown in thin line) only oscillate in the plane shown, i.e. it is assumed that internal waves are seiches (not affected by earth's rotation). (a) V1H1 mode, (b) V2H1 mode and (c) V1H2 mode. Estructura idealizada de ondas internas. Aquí se a asumido que las isotermas (mostradas en línea fina) solo oscilan en un plano vertical, $i$. e. se asume que las ondas internas son secas (no afectadas por la rotación de la tierra). (a) modo V1H1, (b) modo V2H1 y (c) modo $\mathrm{V} 1 \mathrm{H} 2$.

and troughs (negative IPE values). The spatial structure of the Poincaré mode is shown in figure 11 . The phase propagates anti-cyclonically around the basin. The behaviour of the IPE oscillations in the surrounding embayments, though, does not follow the basin-scale pattern. For example, in Fig 11 a, b, the wave is causing upwelling in the western shore in the main basin (high positive $I P E$ ) while close to the shore in the embayment the IPE signal shows negative values (downwelling). The IPE in the embayment oscillates with a node along the East-West direction, contrary to the general behaviour in the main deep basin. The horizontal structure of the oscillations is, thus, far from being simple due to the irregular shape of the basin. 


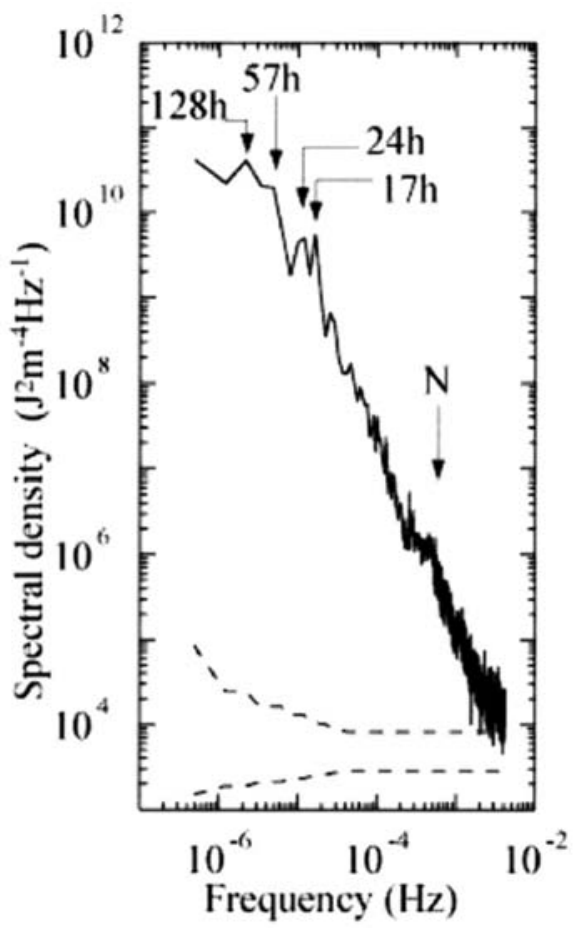

Figure 9. Power spectra of integrated potential energy, IPE, at the INDEX station (Lake Tahoe). Dashed lines indicate $95 \%$ confidence levels. Marked in the figure are the periods corresponding to the peaks in the spectrum. Espectro de frecuencias de las series de tiempo de energía potencial integrada IPE estimada para la estación INDEX (Lago Tahoe). Las lineas discontinuas representan el nivel de confianza del $95 \%$. Sobre la figura se indican los periodos correspondientes a los picos de frecuencia.

\section{Interaction of wind and internal waves}

Figure 12 shows wind and temperature records collected in Lake Tahoe, during the 25-day period studied in Rueda et al. (2003b). Observations at the INDEX station, suggest that three intervals or sub-periods of internal wave activity can be distinguished:

- Interval 1 (days 350 through 357 in 1999) with significant internal wave activity at both subinertial and superinertial frequencies, and amplitudes of up to $30 \mathrm{~m}$;

- Interval 2 (from day 358, 1999 through day 1, 2000) where the subinertial oscillations observed in Interval 1 with periods above 24 hours vanish; the diurnal and superinertial periodicity dominate during this interval;
- Interval 3 (from day 2, 2000 to the end of the record) when the wind again excites the internal waves at the periods previously observed during Interval 1.

The evolution of the internal wave energy can be explained by analyzing the relative phase between the wind and the internal oscillations. A well known result in classical mechanics is that the amplitudes of the motions described by a forced harmonic oscillator depend on the energy of the forcing mechanism, the frequency of the forcing compared with the natural frequency of the oscillator, and their relative phase (see for example Wilson 1972). The Kelvin wave signal in the observed IPE time series at the INDEX station was extracted from the raw IPE signal using wavelet transforms (e.g. Torrence and Compo 1997) and plotted together with the East-West wind component at the USCG weather station in figure 13. An increase in the IPE time series marks an upwelling at the western shore of the lake, while downwelling periods correspond to decreasing trends in the series. Easterly winds acting at the time of upwelling will act to energize the internal wave (energizing event), as they act in phase. Easterly winds acting at the time of downwelling will drain energy from the internal wave (weakening event). In figure 13 the energizing events are marked with dark gray bars, while the weakening events are marked with light gray bars. The decay in the Kelvin wave amplitude follows a series of weakening events, while a series of energizing events precedes the excitation of Kelvin waves in the subperiod 3. These results suggest that the internal wave climate in lakes is, in general, the result of a complex and subtle interaction of atmospheric and the own internal wave features (their frequency, intensity and duration, as well as their spatial characteristics), which, in turn, is controlled by stratification, morphology and the Earth's rotation. The analysis of the internal waves in large lakes, hence, requires the use of dynamic timevarying (e.g. 3D hydrodynamic models or wavelets) rather than static (classical power spectrum density, etc) or spatially-simplified (2-D or 1-D hydrodynamic models) tools. 
H1
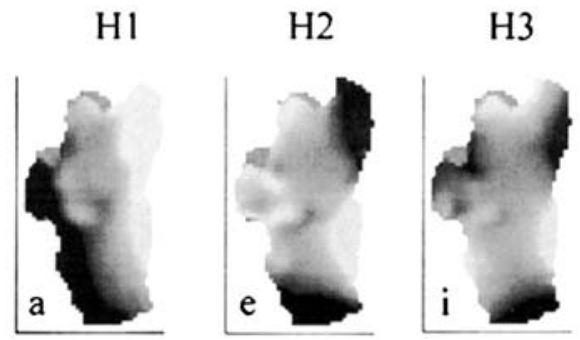

$\mathrm{T} / 4$
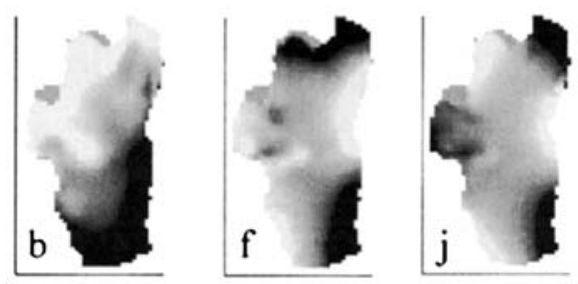

$T / 2$
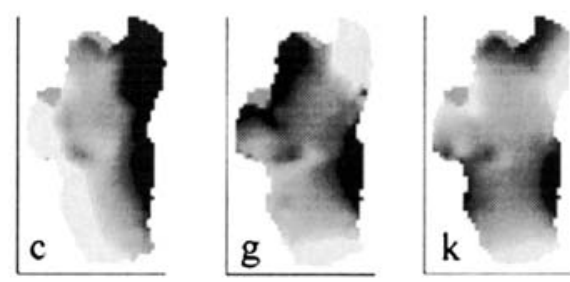

$3 \mathrm{~T} / 4$
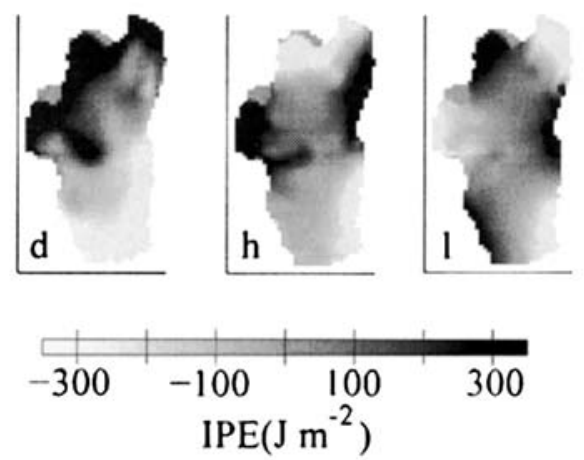

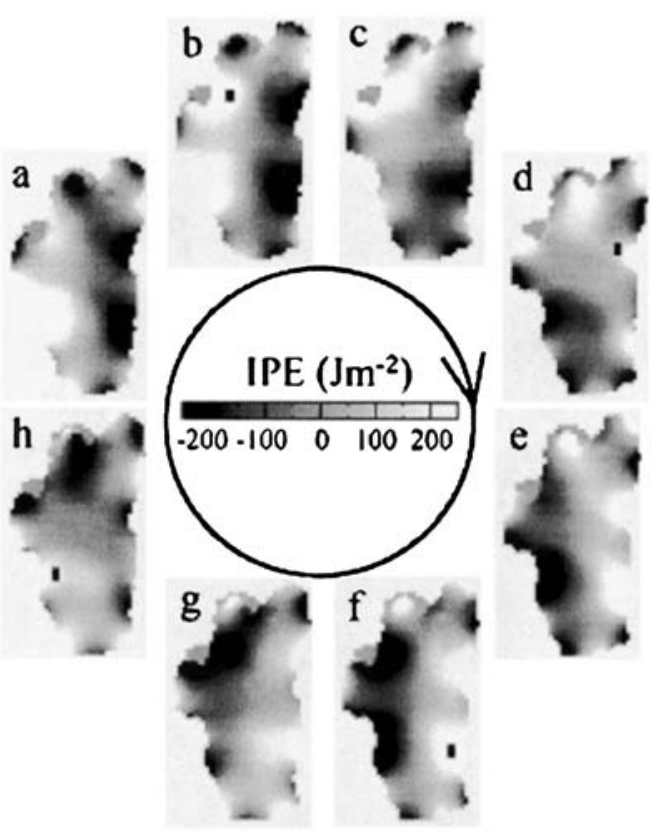

Figure 11. First mode Poincaré wave in Lake Tahoe reproduced in the modeled IPE and presented at 2 hour intervals. Wave period is approximately $17 \mathrm{~h}$. The arrow on the circle indicates the direction of time advance. The sense of rotation of the internal wave is anti-cyclonic. Time series of IPE at each horizontal location are processed as indicated in Figure 10. A black box is included to display the clockwise phase propagation of the Poincaré wave. Primer modo de la onda de Poincaré en Lake Tahoe, según el modelo de simulación. Se presenta la estructura horizontal del las desviaciones de IPE en relación a su valor promedio en cada punto. La estructura se muestra cada dos horas. El período es de aprox. 17h. La flecha en el círculo interior indica la dirección de avance del tiempo. El sentido de rotación de estas ondas es anticiclónico. Un cuadrado negro se ha utilizado para poner de manifiesto la propagación a favor de las aguas del reloj de la onda de Poincaré.

\section{SEMI-ENCLOSED SYSTEMS IN LITTORAL REGIONS}

Under the action of upwelling favourable events nutrient-rich deepe water reaches the surface in near-shore regions, hence, inducing changes in the abundance and structure of the phytoplankton communities in littoral systems, such as semi-enclosed embayments. Data collected in Little Sodus Bay (LSB, 4320' N - 76² $42^{\prime} 30^{\prime \prime}$ W, Fig. 14), a small embayment on the south shore of LO, is very suggestive in this regard (Fig. 15). LSB is approximately $4 \mathrm{~km}$ long and $1 \mathrm{~km}$ wide, and it is permanently connected to LO through a 


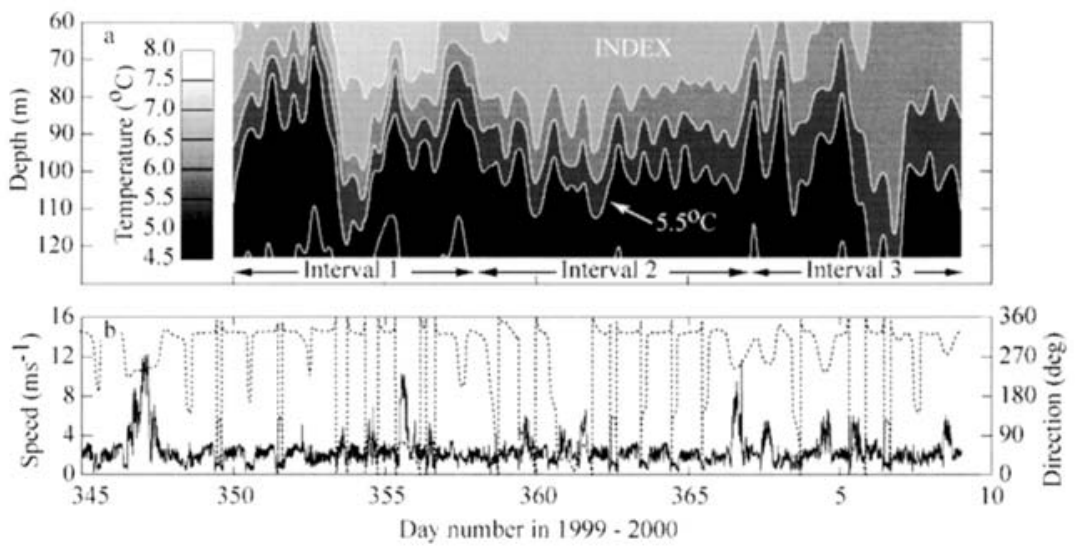

Figure 12. Time series of (a) isotherm depths at the INDEX station, and (b) wind speed and direction in Lake Tahoe. Isotherms in frames (a) are shown every $0.5^{\circ} \mathrm{C}$. The $5.5^{\circ} \mathrm{C}$ has been marked for reference. The period under analysis started on day 350, 1999 (December 16), and ended on day 9, 2000 (January 9). Series de tiempo de (a) profundidad de las isotermas en la estación INDEX, y (b) velocidad y dirección del viento en el lago Tahoe. Las isotermas se muestran cada $0.5^{\circ} \mathrm{C}$, y la isoterma de $5.5^{\circ} \mathrm{C}$ ha sido marcada como referencia. El periodo analizado en Rueda et al. (2003b) comienza en el día 350, 1999 (16 de diciembre), y finaliza el día 9, 2000 (9 de enero).

man-made channel with design length, width, and depth of 550,75 , and $3 \mathrm{~m}$, respectively. During summer, upwelling events in LO occur episodically along its southern shore in response to strong and sustained easterly winds ${ }^{1}$ (see Rueda and Cowen, 2005), and consequently LSB is exposed to nutrient-rich LO hypolimetic water. Secchi disk depth measurements were taken in LSB (Hairston and Doyle, personal communication) and compared with the time series of easterly wind impulse $I$ (see section 3 for definition of $I$ ) in LO during several months in 2001. Upwelling events occur if the alongshore easterly wind impulse is larger than a threshold value (marked in figure 1 with crosses), determined by stratification conditions in the water column and the magnitude of offshore (southerly) winds (Csanady 1977). Thermal stratification in LO is presumed constant, characterized by a $14 \mathrm{~m}$ deep thermocline and a reduced gravity $\left(\mathrm{g}^{\prime}=\mathrm{g} \Delta \rho / \rho\right)$ of c.a. $1.5 \times 10^{-3} \mathrm{~m} \mathrm{~s}^{-2}$, typical of summer conditions (Schwab 1977). The Secchi depth time series shows cyclic changes, which are typical of lake environments (see for example figure 7 in Thomann et al. 1981). Each

\footnotetext{
1 The Rossby radius of deformation in Lake Ontario during summer is lower than the average width of the lake $(>100 \mathrm{~km})$, hence, upwelling occurs in response to along-shore winds (see section 3).
}

of the three upwelling events that occurred in the three summer months of 2001 precede periods of decreases in water transparency, as indicated by negative trends in the Secchi depths. In Rueda and Cowen (2005) it was hypothesized that these decreases in transparency are the result of increased biological activity.

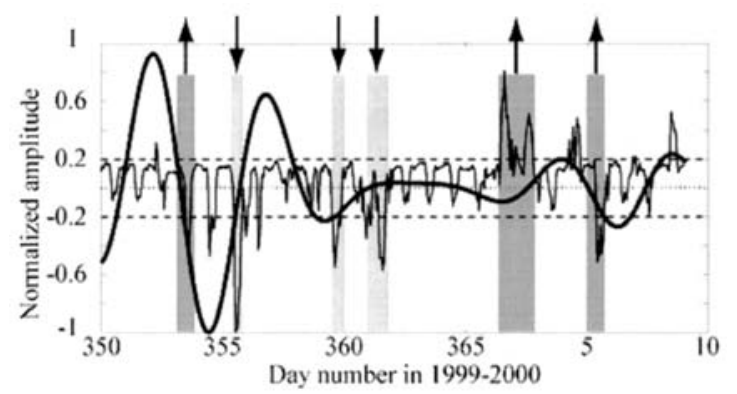

Figure 13. Measured IPE signal at the INDEX station for the first horizontal mode Kelvin wave (as calculated through wavelets) and East-West component of the wind vector. The time series have been normalized using the maximum value during the time window analyzed. Vertical dark gray bars mark strong wind events when the phase of wind and the Kelvin wave results in the wave being enhanced (also indicated by a vertical arrow pointing upwards). Light gray bars mark events when the interaction is destructive (downward looking arrow). Series de tiempo de (a) profundidad de las isotermas en la estación INDEX, y (b) velocidad y dirección del viento en el lago Tahoe. Las isotermas se muestran cada $0.5^{\circ} \mathrm{C}$, y la isoterma de $5.5^{\circ} \mathrm{C}$ ha sido marcada como referencia. El período analizado en Rueda et al. (2003b) comienza en el día 350, 1999 (16 de diciembre), y finaliza el día 9, 2000 (9 de enero). 
Whether fluctuations in biological activity shown in the LSB data reflect an endogenous response of the system or are driven by exogenous (upwelling) influences, it remains to be proved, but what Rueda and Cowen (2005a and 2005b) showed was that the hydrodynamic behaviour of LSB undergo significant changes during upwelling events in LO. The work of Rueda and Cowen (2005a and 2005b) used the hydraulic residence time as a surrogate and single-value description of the transport characteristics of LSB. The residence time was estimated from the analysis of simulated tracer release experiments, consisting on releasing a certain amount of mass $m_{0}$ of a conservative tracer at time $t_{0}$ and at location $\alpha$ in LSB. The time varying tracer mass $m(t)$ remaining in LSB was then monitored. The quantity $m(t)$ is found from the spatial integration of the measured concentration field within the water body, and its decline over time reflects the net rate at which tracer leaves the water body. The rate of mass loss as a function of time $r(t)$ provides the residence time distribution $\operatorname{RTD} \varphi(t)$,

$$
r(t)=-\frac{1}{m_{0}} \frac{\mathrm{d} m}{\mathrm{~d} t}
$$

which is the probability density function of the residence time of the ensemble of individual particles released at the beginning of the experiments. Equation 6 shows that the RTD has units of $[\mathrm{T}]^{-1}$. The mean residence time, based on the first moment of $r(t)$, can then be calculated as

$$
\tau_{r}=\int_{0}^{\infty} r(t) t \mathrm{~d} t=-\frac{1}{m_{0}} \int_{0}^{\infty} \frac{\mathrm{d} m}{\mathrm{~d} t}=\frac{1}{m_{0}} \int_{0}^{\infty} m(t) \mathrm{d} t
$$

If instead of releasing tracer at location $\alpha$, one presumes a release in which the whole water body is initially and uniformly filled with a mass $m_{0}$ of a conservative tracer, Eq. 6 yields the flushing time distribution (see Rueda and Cowen 2005b). The mean flushing time is estimated as in Eq. 7, and it provides a bulk or integrative description (with no spatial dependence) of the transport characteristics of a water body.

As Eq. 6 suggests, the residence or flushing time in LSB, and in any other aquatic system, is dictated by he rate at which water parcels leave

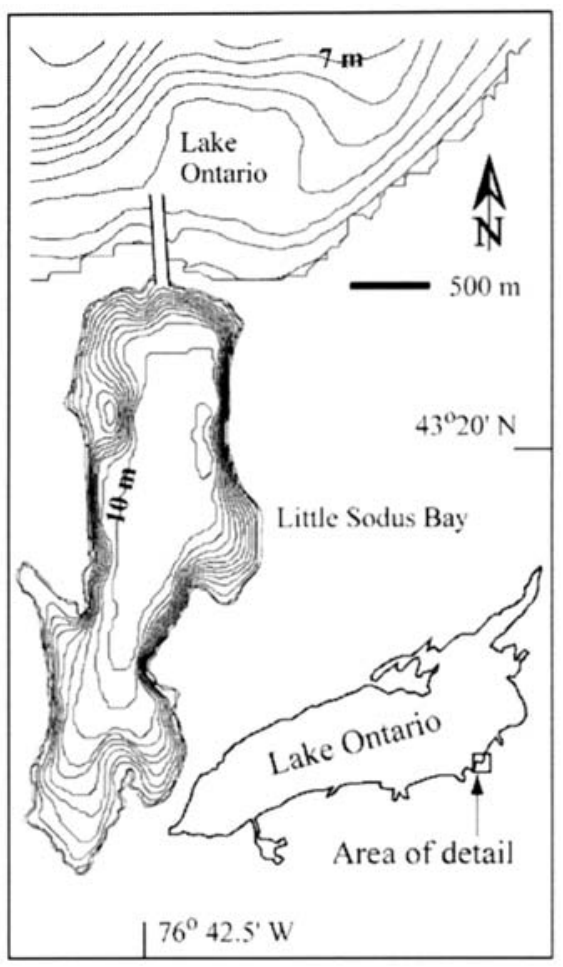

Figure 14. Location and bathymetric map of Little Sodus Bay. Contours are shown every meter, and the $10-\mathrm{m}$ and $7-\mathrm{m}$ isobaths are shown in Little Sodus Bay and Lake Ontario, respectively. The bay is connected to the lake through a channel that is $550 \mathrm{~m}$ long, $75 \mathrm{~m}$ wide, and $3 \mathrm{~m}$ deep. Localización y batimetría de Little Sodus Bay. Los contornos se muestran a cada metro, y los correspondientes a 10 y 7 m se muestran en Little Sodus Bay y Lago Ontario, respectivamente. LSB está conectada al Lago Ontario por un canal de $550 \mathrm{~m}$ de longitud, $75 \mathrm{~m}$ de anchura y $3 \mathrm{~m}$ de profundidad media.

the system. The processes involved in the transport of water parcels from any point in the embayment until they reach the lake can be classified, for the sake of clarity, into "exchange" processes, acting in the channel, and "internal mixing" processes, acting within the embayment. The difference between internal mixing and exchange time scales can be better understood using two idealized flow reactor models: the continuous stirred tank reactor (CSTR) and the plug-flow reactor (PFR - e.g. Levenspiel 1999). In the CSTR internal mixing is considered infinitely fast and the mean residence time is set by the rate at which exchange takes place. At the other extreme, in the PFR the mean residence time is controlled by the rate particles move within the reactor (internal mixing in our semantics), and the exchange 

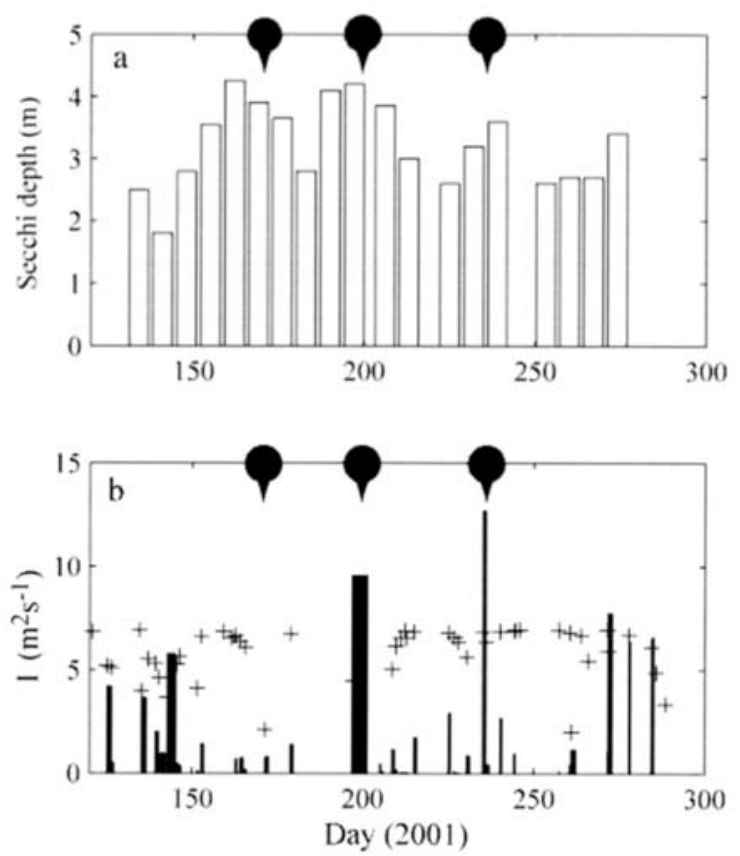

Figure 15. (a) Secchi depth observations (Doyle and Hairston, personal communication) for LSB in 2001. (b) Series of alongshore impulses of upwelling-favorable wind events (bars), and threshold values for the alongshore wind impulse to induce a full upwelling event (crosses). Calculations based on wind records from buoys 45139 and 45135 (operated by Environment Canada) in the northern and western ends of LO, respectively. The arrows in (a) and (b) mark periods when the wind records suggest that upwelling events could have occurred. (a) Observaciones de profundidad del disco de Secchi (Doyle and Hairston, comunicación personal) tomadas en LSB durante 2001. (b) Impulso del viento para eventos procedentes del Este (que provocan el ascenso de las isotermas a lo largo de la costa sur del Lago Ontario) - barras verticales -, junto a valores umbrales para que los eventos puedan llegar a producir afloramiento completo (cruces). Los cálculos se han hecho utilizando los registros de las boyas 45139 y 45135 (operadas por Environment Canada) en el norte y oeste de LO, respectivamente. Las flechas en (a) y (b) marcan periodos en que los registros de viento sugieren que fenómenos de afloramiento se producen a lo largo de la costa sur de LO, frente a LSB.

processes do not set the RTD. Even though exchange and mixing processes are considered separately, they need to be jointly considered in the examination of basin water residence times since they are inextricably linked in the determination of mass fluxes across the channel (e.g. Ivey 2004). The density gradients in the channel, for example, are determined by the density in the respective basins, which is, in turn, influenced by the dynamics within the basins themselves.

\section{Physical processes driving exchange in the channel}

The estimated mean daily discharge $Q$ from the contributing watershed into the embayment is $0.15 \mathrm{~m}^{3} \mathrm{~s}^{-1}$. However, instantaneous discharge measurements taken in the LSB-LO channel during several periods of 2001 and 2002 and under baseline (non-upwelling) conditions were of up to 400 times larger, suggesting that through-flow was negligible in comparison with other exchange mechanisms at the channel scale. Moreover, discharge measurements were of oscillatory nature, indicating that the channel acts both as an inflow and outflow opening. The most energetic oscillations occurred with 2-3 h period, which corresponds to the fourth surface seiche mode in Lake Ontario, inducing water level oscillations of a few $\mathrm{cm}$ range. These results suggest that barotropic forcing (i.e. water level oscillations) is the dominant mechanism of motion under baseline conditions, moving water either towards LO or LSB with little shear (i.e. the water at all depths moved in the same direction, see figure 16a). During LO upwelling events, temperature differences between LO and LSB (in hardly $500 \mathrm{~m}$ ) observed during 2002 were of up $16^{\circ} \mathrm{C}$. In figure $16 \mathrm{~b}$, the temperature differences along the channel $(500 \mathrm{~m})$, during an upwelling event on day 148 in 2002 , are c.a. $6^{\circ} \mathrm{C}$ (Fig. 16b). Temperature records collected at different depths in the channel and velocity measurements at the bottom of the channel, suggest that water from LSB exits the bay through the surface and LO water enters the bay through the bottom of the channel (Figs. 16c and d). The exchange pattern (outflow in the surface, inflow in the bottom) was persistent, indicating that the horizontal density gradients, induced in response to upwelling in LO, became the dominant forcing of exchange between LO and LSB. Furthermore, barolinic forcing is also dictated the by the internal dynamics of the embayment. As shown in Rueda and Cowen (2005a), $L_{N}$ and $W$ can frequently reach values lower than 1 suggesting that isotherm excursions are large compared with the epilimion thickness and persist in time long enough, according to the internal hydraulic theo- 
ry (e.g. Armi and Farmer 1986), to modify the exchange rates through the LSB-LO channel. In any case, either during base-line or upwelling conditions, Rueda and Cowen (2005a) show by scaling analysis that barotropic (water level) and baroclinic (density driven) forcing, wind stress applied at the free surface, frictional, and unsteady effects, all need to be considered in the quantitative analysis of exchange processes through straights in lake environments.

\section{Net exchange rate of mass through lake-embayment connection}

Field data and three-dimensional dynamic simulations for a period of 50 days in 2002, presented in Rueda and Cowen (2005b), showed that the net exchange rates between LO and LSB (the rate at which LSB water is renewed) under base-line (non-upwelling) conditions is at least 10 to 20 times smaller than during upwelling
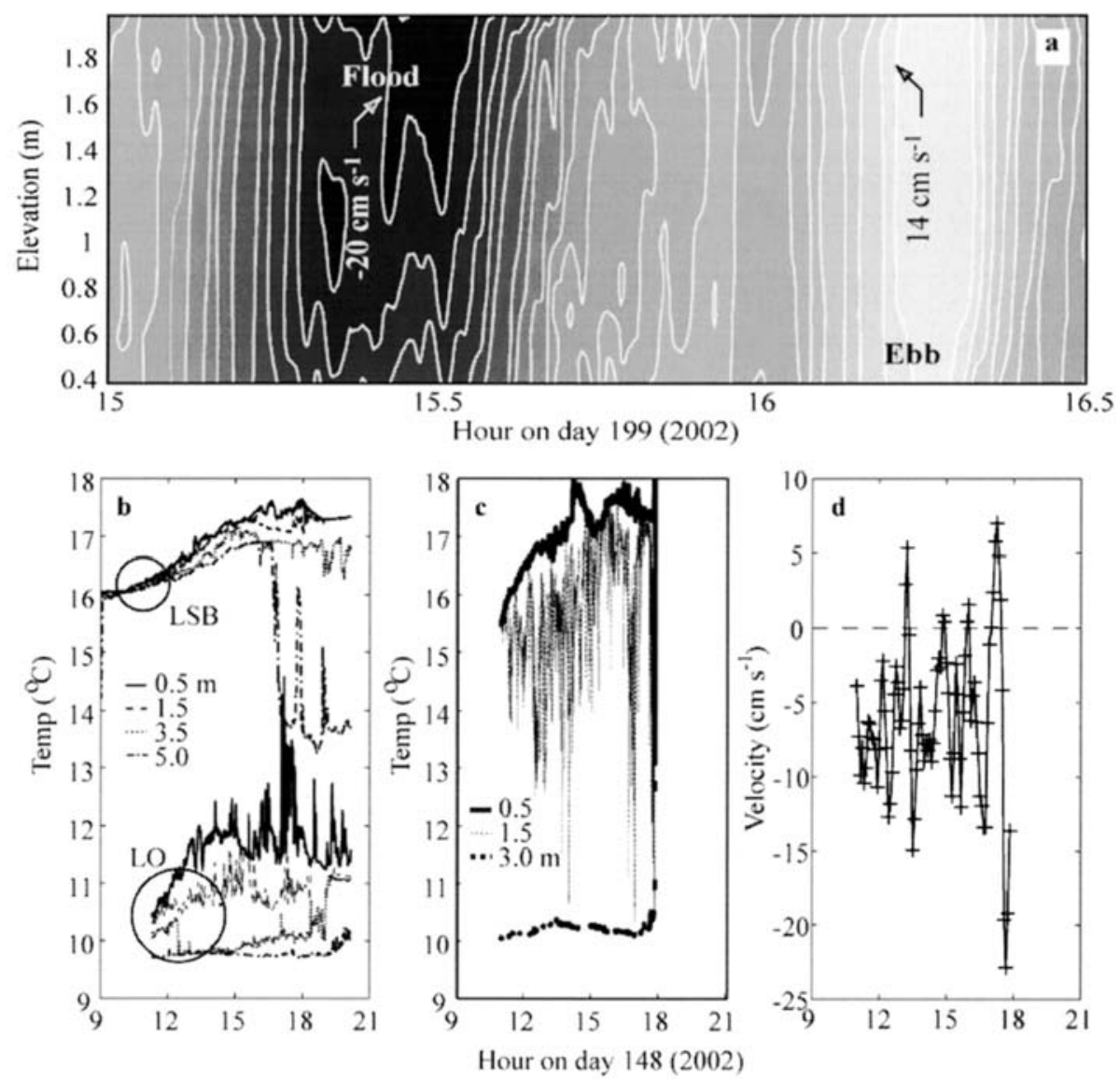

Figure 16. Observation of channel processes in 2002. (a) Time series of longitudinal channel velocity profiles during $11 / 2 \mathrm{~h}$ during base-line (non-upwelling) conditions. Isotachs are shown every $2 \mathrm{~cm} \mathrm{~s}^{-1}\left(-20 \mathrm{~cm} \mathrm{~s}^{-1}\right.$ and $14 \mathrm{~cm} \mathrm{~s}^{-1}$ isotachs are given in the plot), time is represented along the $x$-axis and elevation from the bottom on the $y$-axis. (b), (c) and (d) correspond to upwelling conditions. Time series of (b) temperature at different depths at LO and LSB (near the channel); (c) temperature at 3 depths at the channel; and (d) velocity at the bottom of the permanent connection between Little Sodus Bay and Lake Ontario (negative is flood, i.e., toward LSB). Observaciones en el canal de conexión LSB-LO, tomadas en 2002. (a) Series de tiempo de perfiles del componente de la velocidad del agua paralelo a las paredes del canal (componente Norte-Sur). Los registros corresponden a un periodo de 11/2 $h$ durante condiciones de base (no afloramiento). Lineas de isovelocidad se muestran cada $2 \mathrm{~cm} \mathrm{~s}^{-1}$ (los contornos correspondientes $a-20 \mathrm{~cm} \mathrm{~s}^{-1}$ y $14 \mathrm{~cm} \mathrm{~s}^{-1}$ están marcados). El tiempo se representa en el eje $x$ y la altura sobre el fondo en el eje y. (b), (c) y (d) corresponden a observaciones tomadas durante condiciones de afloramiento en el Lago Ontario. Son series de tiempo de (b) temperatura a diferentes profundidades en LO y LSB (en las inmediaciones del canal); (c) temperatura a tres profundidades en el canal; (d) velocidad medida en el fondo del canal (valores negativos indican que el agua se mueve hacia LSB). 

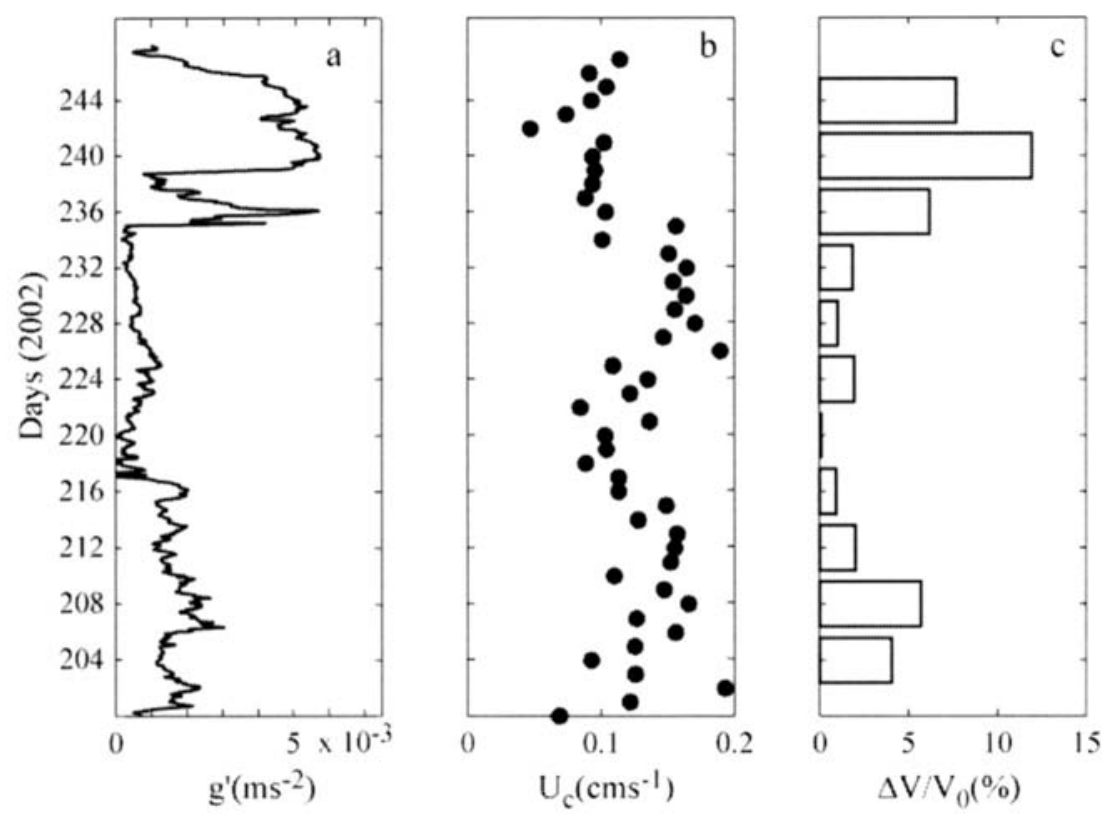

Figure 17. Results of simulated tracer experiments for summer 2002 in LSB. (a) Time series of reduced gravity across the channel joining LSB and LO. (b) Standard deviation of along-channel depth-averaged velocity fluctuations in a 1-day window. Its mangitude is related to the energy of the water level oscillations (barotropic processes) driving exchange. (c) Volumetric exchange rate for the 11 tracer experiments, given in non-dimensional form and as a percentage of the initial embayment volume. Resultados de la simulación de experimentos con trazadores durante el verano de 2002, en LSB. (a) Series de tiempo de la gravedad reducida (relacionada con la diferencia de temperatura a ambos lados del canal). (b) Desviación estándar de las fluctuaciones de velocidad promediada en la dirección vertical, en una ventana de tiempo de un día. Su magnitud es representativa de la energía de las oscilaciones del nivel del agua en LO (procesos barotrópicos) que inducen intercambio de masa entre LSB y LO. (c) Volumen intercambiado en cuatro días para 11 experimentos simulados de trazadores. La posición de la barra en el eje tiempo indica el momento de la liberación del trazador. El volumen se ha adimensionalizado, utilizando el volumen de agua en LSB al comienzo del experimento.

conditions (Fig. 17). Baroclinic forcing (associated with density gradients) is, therefore, a much more effective exchange mechanism than water level fluctuations in littoral embayments. This can be better understood if we apply Stommel and Farmer's 1952 visualization of exchange processes driven by water level changes to LSB inlet, as shown in figure $18 \mathrm{a}$ and $18 \mathrm{~b}$. Note that the same fluid mass is not transferred in and out of the basin on each seiche cycle, the difference being a net, or residual, mass transfer. The volume of water involved in the exchange, a jet during flood (filling of LSB) or the potential flow region during ebb (draining of LSB), will be, in general (but for the case of very small embayments), much smaller than the total volume of the embayment. Scaling arguments show that the average excursion of an individual particle during a typical $2 \mathrm{~h}$ seiche cycle is less than
$500 \mathrm{~m}$ (recall this is the lake-embayment channel length scale), and considerably smaller than the length of the basin $(4 \mathrm{~km})$. The net exchange rate is determined by the rate at which the net water mass introduced during a tidal (event) cycle is mixed with the rest of the embayment water, which the numerical simulations indicate is small. Figure 18c shows, on the other hand, the circulation pattern induced by large temperature gradients in the channel, during upwelling events. During upwelling events gravitational forces (density differences) bring cold LO water into the interior of LSB; lake water advanced as gravity currents and reach the end of the embayment within hours ( $<1$ day) after penetration (see Rueda and Cowen 2005). Warmer LSB water is transported out towards LO through the surface. The whole basin is, therefore, actively involved in the exchange process. 


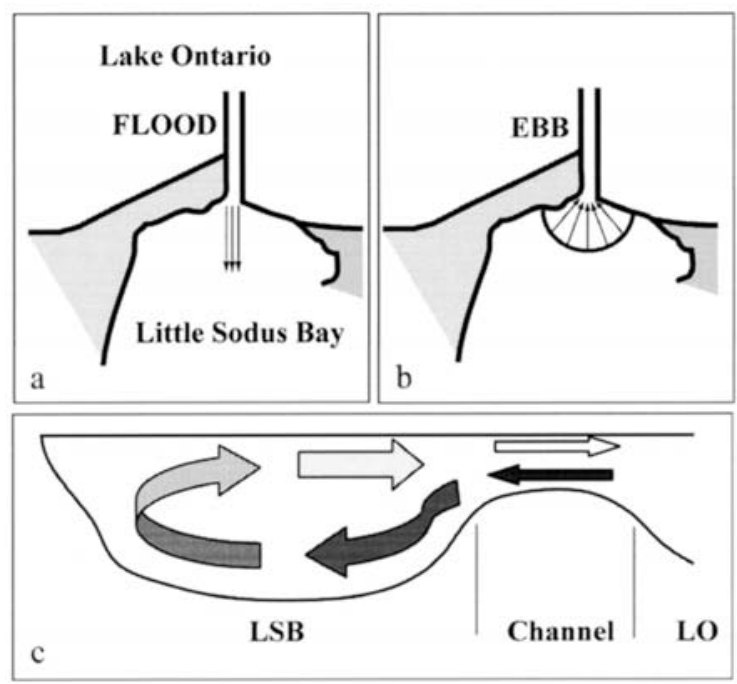

Figure 18. Exchange processes in semi-enclosed basins. (a) and (b) represent Stommel and Farmer's (1952) visualization of flood and ebb flows (barotropic forcing) at an inlet, adapted to the geometry of LSB. (a) The flood flow enters as a confined jet, while the ebb flow waters (b) are drawn from all around the mouth in the form of a potential flow to a sink. (c) Basin-scale circulation in LSB driven by upwelling events in Lake Ontario. Cold LO water enters as a gravity current following the bottom and displaces warm LSB waters out through the channel. Procesos de intercambio en cuencas semicerradas. (a) y (b) representan la visualización, propuesta por Stommel and Farmer's (1952), de los fenómenos de entrada y salida de agua forzadas por cambios en la superficie libre del agua (mareas o secas superficiales), particularizada para la geometría de LSB. (a) La entrada se produce a modo de chorro ('jet'), mientras que a la salida (b) el agua es extraída de una región circular alrededor del canal, como un flujo potencial hacia un sumidero. (c) Circulación a escala cuenca en LSB, forzada por fenómenos de afloramiento en LO. El agua fría de LO entra como una corriente de gravedad, siguiendo el fondo y desplaza el agua cálida de LSB, que sale por la superficie.

The simulation results of Rueda and Cowen (2005b) suggest that the mean residence time $T_{R}$ (estimated as in Eq.6) in freshwater littoral embayments depend on the occurrence of upwelling events, the magnitude of the thermal gradients induced across the connections, their duration, frequency and location in time. In LSB, for example, $T_{R}$ varied from 15 days to 90 days, depending on those features. Long-term 3D simulations conducted in LSB, furthermore, suggest that inter-annual variations in the magnitude of the transport time scales in the embayment are related to year-to-year changes in the number of upwelling events in LO: the larger the number of upwelling events in LO, the smaller the simulated mean residence times in LSB. The control by upwelling frequency of the transport rates has strong implications for the study of spatial patterns of transport in littoral embayments. In LO, for example, the winds are predominantly from the west (Phillips and Almazan 1981); hence, one would expect faster renewal rates (and different biogeochemical behaviour) in embayments located along the west and north shores relative to embayments along the lake's southern and eastern shores.

\section{RIVER WATER RESIDENCE TIME IN RESERVOIRS}

The study of Rueda and Cowen (2005b) showed, among other things, that widely used approaches to calculating residence times in dynamic freshwater systems could be wrong. As pointed by Monsen et al. (2002,) there exists widely spread misconceptions and confusion among aquatic scientists on suitable methods for the determination of residence times in dynamic aquatic systems. In some applications (e.g., Hecky et al., 1993; den Heyer and Kalff 1998) the computation of transport time has been done without specification of the underlying concept used. In other cases, the underlying concept and computational steps have been based on an idealized circumstance that is constrained by critical assumptions, but the validation (or even recognition) of those assumptions has not always been considered when applied to a real river, lake, reservoir or estuary (Monsen et al., 2002). For example, a widely used expression to estimate the 'flushing' time in reservoirs (Foy 1992, Sivadier et al., 1994, Straskraba et al., 1995), consists of dividing the volume of water $V$ stored in the reservoir by the volumetric flow-rate $Q$

$$
T_{f}=\frac{V}{Q}
$$

This expression has also been used in this manuscript as a scale to estimate the importance of advective processes in driving the hydrodynamics of lakes and reservoirs. However, note that 
the name residence time has not been used, purposely, to refer to it. Geyer et al., 2000 defined, instead, the flushing time as "the ratio of the mass of a scalar in a reservoir to the rate of renewal of the scalar", i.e.

$$
T_{f}=\frac{M}{F}
$$

where $M$ is the mass of scalar within the system and $F$ is the flux of the scalar through the domain. Both expressions are equal only if one presumes that the concentration of scalar in the through-flow is equal to the concentration everywhere within the system. This assumption is equivalent to considering that reservoirs act as idealized completely stirred tank reactors CSTR (Levenspiel 1999), where any introduction of mass is instantaneously and evenly mixed throughout the domain. In deep or moderately deep reservoirs the assumption of instantaneous mixing is not valid and complex heterogeneus patterns are usually found (e.g. George 1993). Therefore, Eq. 8 is fundamentally incorrect. Stratification develops in the water column on seasonal time scales and imposes severe restrictions to water movements in the vertical direction. Furthermore, reservoirs are, in general, highly dynamic systems subject to seasonal and short-term variations in discharge rates $Q$ coming in from the watersheds or leaving the reservoirs, or hence in stored volumes. Mediterranean reservoirs, in particular, experience large seasonal and inter-annual level fluctuations as a consequence of their hydrologic behavior characterized (1) by large variations in runoff volumes at the inter-annual scales, and (2) at the seasonal scales by random, scarce and large inflow events concentrated during the winter months together with high water demands (withdrawals) concentrated in the summer months. In highly dynamic systems (such as the Mediterranen reservoirs) it is not clear what values of $Q$ or $V$ should be entered in Eq. 8. Moreover, it is not clear at what temporal averaging scales (i.e. annual, monthly, bi-weekly) should Eq. 8 be valid. Hence, the estimate provided by Eq. 8 is not appropriate for this kind of systems (e.g. Toja 1982 or Pérez-Martínez et al., 1991).

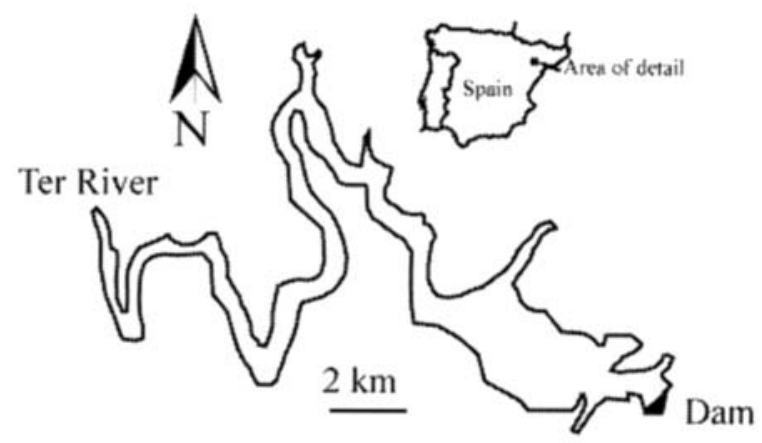

Figure 19. Sau Reservoir in North-Eastern Spain. Embalse de Sau, en el nordeste de España.

Rueda et al. (2005b) reviewed the fundamental concepts of transport time scales in aquatic systems as they apply to reservoirs, and presented a physically-based approach to determining retention time scales in reservoirs. Their approach consisted on simulating tracer releases in the river using physically-based one-dimensional transport models. The mean residence time for river water was estimated, after constructing the RTD (Eq. 6), following Eq. 7. This approach, being based on a physically based description of transport, is fundamentally correct: not only it takes into consideration the effects of stratification on transport, but it is independent of the magnitude of level or discharge fluctuations. Rueda et al. (2006) used this approach (1) to reveal temporal patterns of variation in average retention times of river water and (2) to explore links between hydrodynamic processes and the transport time scales in a reservoir, taken as systems with separated inflow and outflow sections. Sau Reservoir (466'N - 4051'E), a canyon type eutrophic reservoir located in NorthEastern Spain was used in that work as a prototypical example of medium size man-made lakes (Fig. 19). This is the work described here.

Observations collected during 2003 in Sau reservoir were used to drive the tracer simulations. A total of 73 inflow releases (one every 5 days in 2003) were simulated, in order to assess the temporal dependence of mean residence times of river water. The tracer releases were identified by the day of year when the release was done. Rueda et al. (2006) show that the mean residence time $T_{R}$ of river water in 


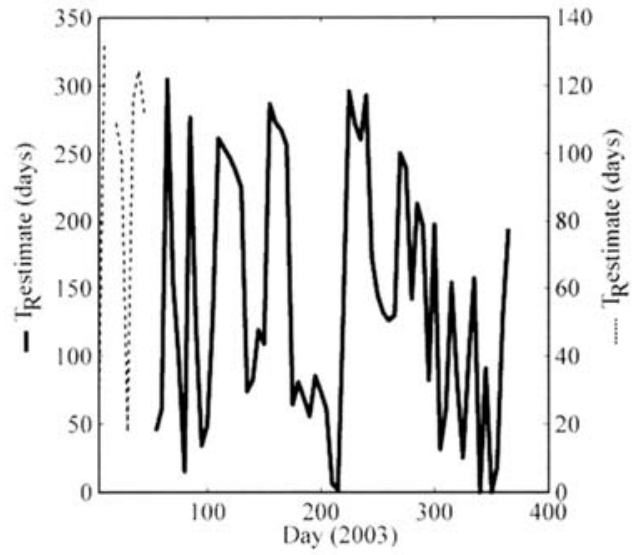

Figure 20. Estimated mean residence time for 73 tracer release experiments simulated with DYRESM. The right scale corresponds to estimates for tracer experiments with release after day 50 in 2003 (solid line). The left scale is for release days before day 50 (dashed line). Tiempo medio de residencia estimado a partir de 73 experimentos simulados de liberación de trazadores. Las simulaciones se hicieron con el modelo de transporte DYRESM. La escala de la derecha corresponde a estimaciones hechas con trazadores liberados después del día 50, 2003 (linea continua). La escala de la izquierda corresponde a trazadores liberados antes del día 50, 2003 (línea discontínua).

the reservoir undergoes temporal changes at a range of scales (Fig. 20), from seasonal to almost-diurnal, associated to the complex interplay of transport processes that determine the fate of river water within the reservoir. The equal-weight average value of $T_{R}$ for the 73 experiments conducted is 75 days similar to that obtained by dividing the average volume by the average through-flow in 2003 (76 days). This similarity is, however, deceiving. The inflow weighted average value of $T_{R}$, considered a more correct estimate of average yearly $T_{R}$, is almost $30 \%$ less than the $V / Q$ estimate (76 days). Moreover, by changing the withdrawal elevation the $V / Q$ estimate does not change, but the average value of $T_{R}$ does: the inflow weighted average $T_{R}$ for 2003 is 65 days.

The pathways followed by river water entering the reservoir on any given day $t_{0}$ from the inflow point to the outlet was analyzed, as they determine the value of $T_{R}$. The pathways are controlled by: (1) the transport and mixing processes that occur at the inflow section, which determine the elevation, relative to the outlet, at which river water penetrates in the reservoir (intrusion layer) and (2) the interplay of advective and turbulent diffusion (mixing) processes which determine the vertical migration of the river water layer towards the outlet elevation. The most energetic mixing processes occur close to the surface, driven by wind or surface cooling, and hence the probability that mixing processes participate in determining the fate of river water in the reservoir will depend on the depth of intrusion. Vertical advection of any given layer formed by intrusion of river water on $t_{0}$ is the result of the net extraction of water separating the intrusion layer and the outlet, which depends on (1) the withdrawal history (withdrawal elevation, volume, etc.) and (2) the river water insertion history after $t_{0}$. In Rueda et al. (2006), it was presumed that there were no changes in the withdrawal elevation. The inclusion of these operational changes would have modified the numerical estimates of residence time scales, by changing the thermal structure and the distance from intrusion depth to the outlet (e.g. Fontane and Labadie 1981, Casamitjana et al., 2003). However, the factors governing residence times under changing withdrawal elevations are the same as described in Rueda et al. (2006).

\section{SUMMARY AND CONCLUSIONS}

As suggested by Ramon Margalef's Mandala, the physical processes of transport and mixing exert a profound influence on the biogeochemistry of aquatic systems. Not only they determine the position of particulate and dissolved substances contained in the water at any given time, but they also contribute to determine the environment in which biogeochemical reactions occur $(\mathrm{pH}$, dissolved oxygen, light, etc). This work has reviewed the behaviour of a range aquatic systems, trying to illustrate that the mechanisms of transport at play in any given environment are determined by both the properties of the external forcing and the characteristics of the system itself (morphology, in particular). As shown in Eqs. 1 and 2, both features (those of the external forcing and intrinsic of the system) are taken into account in the definition of the non-dimensional 
Lake $\mathrm{L}_{\mathrm{N}}$ and Wedderburn $\mathrm{W}$ numbers. They provide a first order description of the physical behaviour of lakes of small and medium size in response to perturbation (wind or hydrologic) events. Scaling arguments, based on length scales (the Rossby radius of deformation $\Lambda$ compared with the average width of a system) or on time scales (the ratio of the volume $V$ and the average through-flow $Q$ ) have also been used to parameterize the influence of the Earth's rotation or advective processes on the hydrodynamics of lakes and reservoirs. These scaling arguments, based on $L_{N}, W, \Lambda$ and $T_{R}$ provide a simple and first order framework in which one can sketch and classify the physical behaviour of aquatic systems. A number of systems has been analyzed in this work to explore a wide range of possible, but not all, combinations existing in this four dimensional domain. Transport, however, in lakes and reservoirs is a dynamic feature and, therefore, the exact details of how fluxes of mass and energy into the systems (their magnitude, frequency, exact location in time, their spatial variability) determines the large scale circulation in these systems. In this revision some of those 'second order' effects, not captured in the first order analysis based on simple scales or nondimensional parameters, have been presented.

In Clear Lake, and in particular in one of its sub-basins (the Oaks Arm) the interaction of a strong, directional and periodic wind with a weak stratification has been examined. Clear Lake is polymictic and exhibits a weak and intermittent stratification, in part, due to being shallow (maximum depth of $15 \mathrm{~m}$ ) and subject to strong winds. $L_{N}$ and $W$ are, in general, much lower than 1 and $\Lambda$ is of the same order as the averaged width of the Oaks Arm. The interaction of wind, stratification and the Earth's rotation, occurring with a diurnal periodicity, generates a net cyclonic residual circulation. The spatial variability of the wind is also responsible for creating circulation in shallow lakes and, therefore, establishing the exchange rates among subbasins. In Lake Tahoe, we have explored the internal waves processes which occur in lakes with $\mathrm{L}_{\mathrm{N}}>1$ and $\mathrm{W}>>1$. Rotational effects ( $\Lambda<19 \mathrm{~km}$, the width of Lake Tahoe) bring in new 'creatures' in the internal wave 'zoo': internal waves are either Kelvin or Poincaré waves. The spatial characteristics are complex and inherently three dimensional. Also, it has been shown that the energy contained in the internal wave field varies in time and is a strong function of the relative phase between wind and the internal waves themselves. In contrast to Clear Lake and Lake Tahoe, which are enclosed freshwater systems where hydrodynamic processes are driven by surface (mechanical or heat) fluxes, the other two cases presented (Little Sodus Bay and Sau reservoir) are semi-enclosed or open systems, where energy and mass fluxes occur at either unique or distinct inflow and outflow sections: $T_{R}$ in these two cases is $<1$ year, compared with 3 years or 500 years in Clear Lake and Lake Tahoe respectively. In LSB, a semi-enclosed system, there is a unique forcing section: the channel between LO and LSB. It is shown there that the net exchange rate of mass across the channel is largely determined by the occurrence of upwelling events in LO and their characteristics (magnitude of temperature gradients induced along the channel, duration, frequency and location in time). In Sau, with distinct inflow and outflow sections, the estimates of residence times of river water were shown to be dependent on the interplay between processes resulting from the water exchange at those sections, as well as the vertical mixing rates. The residence time estimates are subject to variations in time, on a wide range of scales: from seasonal to scales lower than a week.

Through the exploration of transport patterns in four different systems, it has been shown that physics in lakes and reservoirs is far from simple. Transport is not only inherently three-dimensional, but also subject to a considerable variability on a wide range of scales. Transport patterns vary according to characteristics of the external forcing (which can be arguably thought as stochastic) and the own and fixed characteristics of the water body. The range of transport patterns can be, therefore, large. However, although complex, it is possible, through scaling analysis together with the use of advanced numerical and observational techniques, to determine (leaving some margin for observational and numerical 
error) the particular transport patterns that occur in response to a given forcing scenario. It is plausible to think that the links between transport patterns and the biogeochemical behaviour of systems could be explored using similar techniques. However, this exploration poses a serious challenge, since it would require that physical and biological sampling be carried on similar spatial and temporal scales.

\section{ACKNOWLEDGEMENTS}

The modelling work carried in Sau reservoir was done using CWR-DYREMS one dimensional transport model. The author would like to thank the Center for Water Research CWRUniversity of Western Australia for making the model available for use in this work. Also, I want to thank my advisors, staff and research colleagues from the University of CaliforniaDavis and Berkeley, Stanford University, United States Geological Survey, Cornell University, Universidad de Granada and Universidad de Barcelona, for his invaluable help in conducting the research mentioned in this work. This research was conducted with support from several agencies and projects: the Spanish Ministry of Education and Science who supported the author during his $\mathrm{PhD}$ studies at the University of California-Davis, the U.S. Environmental Protection Agency (R819658 \& R825433) sponsored Center for Ecological Health Research (CEHR) at UCDavis, the U.C. Toxic Substances Research and Teaching Program, the Ecotoxicology Lead Campus Program at UC Davis, the National Science Foundation (grant OCE-9906924), a grant from the U.S. Environmental Protection Agency's Science to Achieve Results (STAR) program, National Science Foundation (NSF) Biocomplexity in the Environment Program (OCE-0083625) and National Science Foundation (NSF), CTS0093794, and the Office of Naval Research (ONR) N00014-98-1-0774, Spanish Ministry of Science and Technology (project REN20012185-C02-02) and Water Supply Agency ATLL (contract for the study of Sau reservoir).
In particular, I would like to express my gratitude to Joan Armengol for this kind invitation to submit this contribution to this special issue of Limnetica in homage to Ramon Margalef.

\section{REFERENCES}

ANTENUCCI, J. P. \& J. IMBERGER. 2001. Energetics of long internal gravity waves in large lakes. Limnol. Oceanogr., 46(7), 1760-1773.

ANTENUCCI, J. P. \& J. IMBERGER. 2003. The seasonal evolution of wind / internal wave resonance in Lake Kinneret. Limnol. Oceanogr., 48, 2055-2061.

ANTENUCCI, J. P., J. IMBERGER \& A. SAGGIO. 2000. "Seasonal evolution of the basin scale internal wave field in a large stratified lake." Limnol. Oceanogr., 45(7), 1621-1638.

BAINES, P. G. 1995. Topographic Effects in Stratified Fluids. Cambridge University Press, Cambridge, United Kingdom. 482 pp.

CASAMITJANA, X., T. SERRA, J. COLOMER, C. BASERBA \& J. PÉREZ- LOSADA.. 2003. Effects of the water withdrawal in the stratification patterns of a reservoir. Hydrobiologia, 504: 21-28.

CSANADY, G. T. 1977. Intermittent 'full' upwelling in Lake Ontario. J. Geophys. Res., 82: 397-419.

CSANADY, G. T. (1982). Circulation in the Coastal Ocean, D. Reidel Publishing Company, Dordrecht, Holland. 279 pp.

DEN HEYER, C. \& J. KALFF. 1998. Organic matter mineralization rates in sediments: A within- and among-lake study. Limnol. Oceanogr., 43: 695-705.

FISCHER, H. B., E. J. LIST, R. C. Y. KOH, J. IMBERGER, \& N. H. BROOKS. 1979. Mixing in Inland and Coastal Waters. Academic Press. 483 pp

FONTANE, D. G., \& J. W. LABADIE. 1981. Optimal control of reservoir discharge quality through selective withdrawal. Water Resources Research, 17: 1594-1604.

FOY, R. H. 1992. A phosphorus loading model for Northern Irish Lakes. Water Research, 26: 633638.

GEORGE, D. G. \& M. A. HURLEY. 2003. Using a continuous function for residence time to quantify the impact of climate change on the dynamics of thermally stratified lakes. J. Limnol., 62: 21-26.

GEYER, W. R., J. T. MORRIS, F. G. PAHL \& D. J. JAY. 2000. Interaction between physical processes and ecosystem structure: A comparative approach, In: Estuarine Science: A synthetic approach to 
research and practice. J. E. Hobbie (ed.): 177210. Island Press.

HECKY, R.E., P. CAMPBELL \& L.L. HENDZEL. 1993. The stoichiometry of carbon, nitrogen, and phosphorus in particulate matter of lakes and oceans. Limnol. Oceanogr., 38: 709-724.

HODGES, B. R., J. IMBERGER, A. SAGGIO, \& K. B. WINTERS. 2000. Modeling basin-scale motions in a stratified lake. Limnol. Oceanogr., 45(7), 1603-1620.

HUTTER, K. 1984. Linear gravity waves, Kelvin waves and Poincare waves, theoretical modelling and observations. In: Hydrodynamics of Lakes. K. Hutter (ed.): 39-80. Springer Verlag, WienNew York.

IMBERGER, J. 1998. Flux paths in a stratified lake: A review. In: Physical Processes in Lakes and Oceans, Coastal Estuarine Stud., vol. 54. J. Imberger (ed.): 1 - 17. AGU, Washington, D. C.

IMBERGER, J., \& J. C. PATTERSON. 1990. Physical Limnology. Advances in Applied Mechanics, 27, 303-475.

IMBODEN, D. M. \& A. WUEST. 1995. Mixing mechanism in lakes. In: Physics and Chemistry of Lakes. A. Lerman, D. Imboden \& J. Gat (eds.): 83138. Springer.

IVEY G. N. 2004. Stratification and mixing in sea straits. Deep Sea Research II, 51: 441-453.

LEVENSPIEL, O. 1999. Chemical Reaction Engineering, John Wiley \& Sons. 668 pp.

LYNCH, M. G. 1996. Seasonal variations in lake mixing, Clear Lake, California. Master's Thesis, University of California, Davis. 90 pp.

MACINTYRE, S. 1998. Turbulent mixing and resource supply to phytoplankton. In: Physical Processes in Lakes and Oceans, Coastal and Estuarine Studies. AGU., vol. 54: 561-590. J. Imberger. AGU, Washington, D. C.

MARGALEF, R. 1997. Our biosphere. Excellence in Ecology Books. Vol. 10. Institute of Ecology. $176 \mathrm{pp}$.

MONSEN, N. E., J. E. CLOERN, L. V. LUCAS, \& S. G. MONISMITH. 2002. A comment on the use of flushing time, residence time, and age as transport time scales. Limnol. Oceanogr., 47, 1545-1553.

PAN, H., R. AVISSAR, \& D. B. HAIDVOGEL. 2002. Summer circulation and temperature structure in Lake Kinneret. Journal of Physical Oceanography, 32, 295-313.

PÉREZ-MARTÍNEZ, C., R. MORALES-BAQUERO \& P. SÁNCHEZ-CASTILLO. 1991. The effect of the volume decreasing on the trophic status in four reservoirs from Southern Spain. Verh. Internat. Verein. Limnol., 24: 1382-1385.

PHILLIPS, D. W. \& J. A. ALMAZAN. 1981. Meteorological Analysis. In: IFGL - The International Field Year For the Great Lakes. E. J. Aubert \& T. L. Richards (eds.): 17-50. NOAA, Ann Arbor, Michigan.

REYNOLDS, C. S. 1997. Vegetation Processes in the Pelagic: A Model for Ecosystem Theory. Excellence in Ecology Books. Vol. 9. Institute of Ecology. 404 pp.

RUEDA, F. J. \& E. A. COWEN. 2005a. Exchange between a freshwater embayment and a large lake through a long shallow channel. Limnol. Oceanogr., 50: 169-183

RUEDA, F. J. \& E. A. COWEN. 2005b. The residence time of a freshwater embayment connected to a large lake. Limnol. Oceanogr., 50: 1638-1653.

RUEDA, F. J., E. MORENO-OSTOS \& J. ARMENGOL. 2006. The residence time of river water in reservoirs. Ecological Modelling, 191: 260-275.

RUEDA, F. J., \& S. G. SCHLADOW. 2003. Dynamics of a large polymictic lake. II: Numerical simulations. ASCE Journal of Hydraulic Engineering, 129: 92-101.

RUEDA, F. J., S. G. SCHLADOW, S. G. MONISMITH \& M. T. STACEY. 2003a. Dynamics of a large polymictic lake. I: Field observations. ASCE Journal of Hydraulic Engineering, 129: 82-91.

RUEDA, F. J., S. G. SCHLADOW, S. G. MONISMITH \& M. T. STACEY. 2005a. On the effects of topography on wind and the generation of currents in a large multi-basin lake. Hydrobiologia, 532: 139-151.

RUEDA, F. J., S. G. SCHLADOW \& S. O. PALMARSON. 2003b. Basin-scale internal waves in a deep alpine lake: theory, observations and numerical simulations. Journal of Geophysical Research Oceans, 108(C3).

SCHWAB, D. J. 1977. Internal free oscillations in Lake Ontario. Limnol. Oceanogr., 22, 700-708.

SIVADIER, F., J. M. THÉBAULT \& M. J. SALENÇON. 1994. Total phosphorus budget in Pareloup reservoir. Hydroécol. Appl., 6: 115-138.

SMITH, P. E. 1997. A three-dimensional, finite-difference model for estuarine circulation. Ph.D. Dissertation. University of California, Davis. $217 \mathrm{pp}$.

STEVENS, C. \& J. IMBERGER. 1996. The initial response of a stratified lake to a surface shear stress. J. Fluid Mechan., 312: 39-66.

STOMMEL, H. \& H. G. FARMER. 1952. On the Nature of Estuarine Circulation. References Nos. 
52-51, 52-63, 52-88 (3 vols. containing chapters 1-4 and 7), Woods Hole Oceanographic Institute. STRASKRABA, M., I. DOSTÁLKOVÁ, J. HEJZLAR \& V. VYHNÁLEK. 1995. The effect of reservoirs on phosphorus concentration. Int. Revue ges. Hydrobiol., 80: 403-413.

THOMANN, R. V., D. M. D. TORO, D. SCAVIA, \& A. ROBERTSON. 1981. Ecosystem and water quality modeling. In: IFYGL - The International Year for the Great Lakes. E. J. Aubert \& T. L. Richards (eds.): 353-366. NOAA, Ann Arbor, Michigan.
THOMPSON, K. L. 2000. Winter mixing dynamics and deep mixing in Lake Tahoe. Master's Thesis, University of California, Davis. 125 pp.

TOJA, J., 1982. Control de la eutrofia en embalse por utilización selectiva de agua a distintas profundidades. Revista de Obras Públicas: 223-231.

TORRENCE, C. \& G. P. COMPO. 1997. A practical guide to wavelet analysis. Bulletin of the American Meteorological Society, 79(1): 61-78.

WILSON, B. W. 1972. Seiches. In: Advances in Hydrosciences. V. T. Chow (ed.): 1-94. Academic Press, New York. 